\title{
Wetland Characteristics and Wintering Passerellidae Occupancy on Agricultural Conservation Easement Program Wetlands in West Virginia
}

Katharine Lewis

Follow this and additional works at: https://researchrepository.wvu.edu/etd

\section{Recommended Citation}

Lewis, Katharine, "Wetland Characteristics and Wintering Passerellidae Occupancy on Agricultural Conservation Easement Program Wetlands in West Virginia" (2018). Graduate Theses, Dissertations, and Problem Reports. 7105.

https://researchrepository.wvu.edu/etd/7105

This Thesis is protected by copyright and/or related rights. It has been brought to you by the The Research Repository @WVU with permission from the rights-holder(s). You are free to use this Thesis in any way that is permitted by the copyright and related rights legislation that applies to your use. For other uses you must obtain permission from the rights-holder(s) directly, unless additional rights are indicated by a Creative Commons license in the record and/ or on the work itself. This Thesis has been accepted for inclusion in WVU Graduate Theses, Dissertations, and Problem Reports collection by an authorized administrator of The Research Repository @ WVU. For more information, please contact researchrepository@mail.wvu.edu. 
Wetland Characteristics and Wintering Passerellidae

Occupancy on Agricultural Conservation Easement Program

Wetlands in West Virginia

Katharine Lewis

Thesis submitted to the Davis College of Agriculture, Natural Resources, and Design

At West Virginia University

In partial fulfillment of the requirements for the degree of

Master of Science

In

Wildlife and Fisheries Resources

Christopher T. Rota, Ph.D., Chair

James T. Anderson, Ph.D., Co-chair

Christopher M. Lituma, Ph.D.

Division of Forestry and Natural Resources

Morgantown, West Virginia

2018

Keywords: Agricultural Conservation Easement Program, Appalachians, Wetlands, Wintering Sparrows

Copyright 2018 Katharine Lewis 


\author{
ABSTRACT \\ Wetland Characteristics and Wintering Passerellidae \\ Occupancy on Agricultural Conservation Easement Program \\ Wetlands in West Virginia
}

Katharine Lewis

Wetland ecosystems are unique, important sources of numerous services such as wildlife habitat. Their widespread loss due to drainage and development in North America has promoted the creation of many programs and policies to try to reverse the damage done. One such program is the Agricultural Conservation Easement Program (ACEP). ACEP is administered through the Natural Resources Conservation Service (NRCS) and provides landowners with technical and financial assistance to restore wetlands on private agricultural land. One of the primary objectives of ACEP is to provide wildlife habitat while restoring wetlands in agricultural areas. It is important to monitor conservation practices such as ACEP to determine if the program goals are being met. This can be accomplished by directly studying the wildlife community on these wetlands in combination with assessing overall wetland features and vegetative characteristics. We conducted land-cover, vegetative, and wetland feature assessments on wetlands enrolled in ACEP in West Virginia to determine if ACEP wetlands have similar characteristics to wetlands compared with a set of reference wetlands located on public land. Additionally, we studied the wintering occupancy of new world sparrows on the same wetlands to evaluate how ACEP sites function as wildlife habitat compared to other available wetland habitat in West Virginia. Wetland characteristics between ACEP and reference sites differed in a few areas: the proportion of pasture immediately surrounding wetlands was higher on ACEP sites than reference, and the proportion of forest immediately surrounding sites was higher on reference sites. Additionally, the percent coverage of invasive herbaceous material was higher on reference sites, and seasonal flooding was more likely to be present on ACEP sites. Other characteristics and features including invertebrate diversity did not differ significantly between site types. Two Passerellidae species had higher occupancy probability on ACEP sites over reference sites: swamp sparrows (Melospiza georgiana) and dark-eyed juncos (Junco hyemalis). The small number of differences between wetland characteristics on ACEP and reference sites, coupled with higher wintering sparrow occupancy of two species on ACEP sites indicates that ACEP wetlands in West Virginia are functioning similarly to other wetlands located in West Virginia and provide important, early successional wildlife habitat. 


\section{ACKNOWLEDGEMENTS}

I thank the Natural Resources Conservation Service, the West Virginia University Natural Resources Analysis Center, and Pamela Yost, Joe Hatton and Paul Kinder for their funding and logistical support of this project. I also thank all of the Agricultural Conservation Easement Program wetland owners for welcoming me on to their properties to conduct my research and for their enthusiastic interest in my research. I thank my thesis advisor Dr. Rota and my co-chair and committee members Dr. Anderson and Dr. Lituma for their support and guidance throughout this project. Finally, I thank Conor, my family, and friends for their unwavering encouragement, patience, and field help over the last two years. 


\section{TABLE OF CONTENTS}

Table of Contents

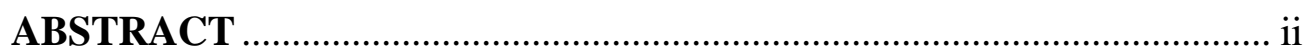

ACKNOWLEDGEMENTS ...................................................................... ii

Table of Contents ..............................................................................................

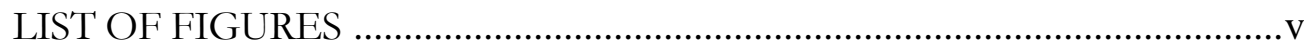

LIST OF TABLES ............................................................................................ viii

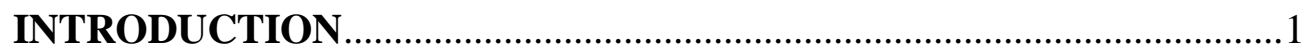

Chapter 1: A Comparison of Surrounding Land-cover, Vegetative Cover, Wetland Features, and Invertebrate Diversity Between Agricultural Conservation Easement Program Wetlands and Wetlands Located on Public Land in West Virginia ........................... 3

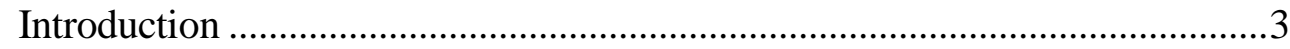

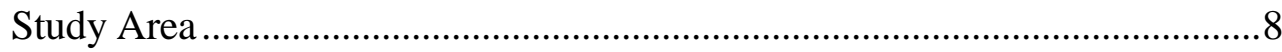

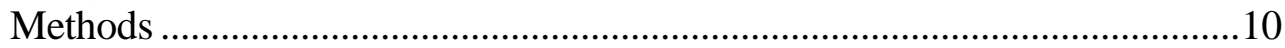

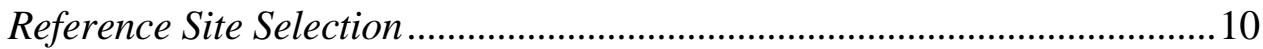

Wetland Characteristics Assessments ........................................................ 10

Statistical Analyses ............................................................................ 11

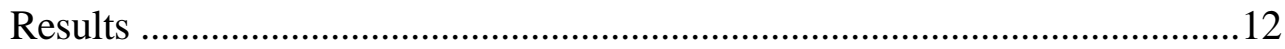

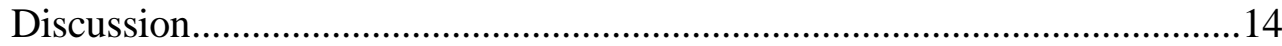

Literature Cited ................................................................................ 33

Chapter 2: Influence of Agricultural Conservation Easement Program Wetland Practices on Winter Occupancy of Passerellidae Sparrows ............................................4 42

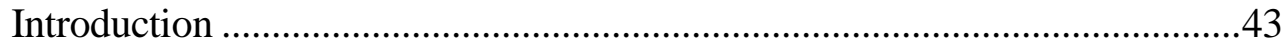

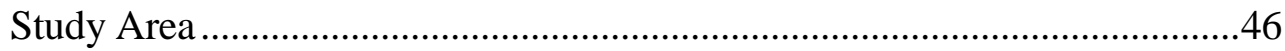

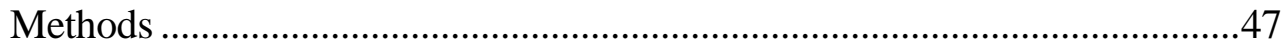

Reference Site Selection ....................................................................... 47

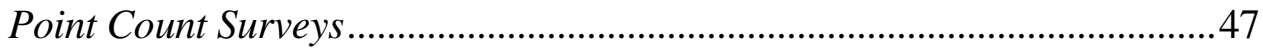

Detection Probability Covariates ..................................................................48

Occupancy Probability Covariates..........................................................49

Statistical Analyses ............................................................................50

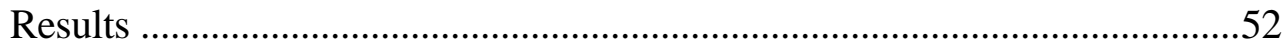

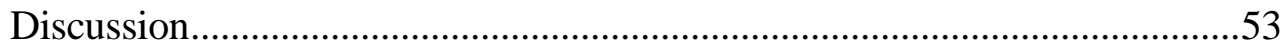

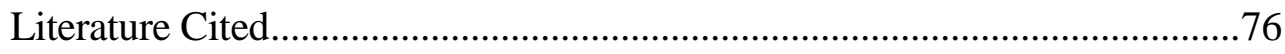

Appendix A: Wetland Site Characteristics of ACEP and Reference Wetlands

. .81

Appendix B: Counts of Macroinvertebrate Families by Site and Associated Shannon-Weaver Diversity Index. 83 


\section{LIST OF FIGURES}

Figure 1-1. All wetlands enrolled in the Agricultural Conservation Easement Program (ACEP) administered through the Natural Resources Conservation Service in West Virginia, USA along with reference wetlands located on public land on wildlife management areas, state parks, and The Nature Conservancy land. Blue squares represent reference sites and red circles represent ACEP wetland sites. 21

Figure 1-2. Example of a 50m buffer separated by $10 \mathrm{~m}$ buffer increments, vegetative transects, and invertebrate sampling locations around an Agricultural Conservation Easement Program wetland site in West Virginia, USA. Red represents the wetland easement boundary. Transects are placed every $78 \mathrm{~m}$, are $50 \mathrm{~m}$ long and are broken into $10 \mathrm{~m}$ increments represented by green dots. Blue dots represent invertebrate sampling locations which were placed approximately evenly around water features and distributed evenly across water features. .22

Figure 1-3. Results of MANOVA analysis conducted on the proportion of land-cover surrounding Agricultural Conservation Easement Program (ACEP) and reference wetlands in West Virginia, USA conducted in May 2017 with land cover category proportions as the response variable and ACEP or reference wetland type as the predictor. Results broken down by the six land-cover categories observed in the 50-meter buffers with $95 \%$ confidence intervals.

.23

Figure1-4. Results of MANOVA analysis conducted on percent coverage of vegetative categories recorded on transects in May of 2017 on Agricultural Conservation Easement Program (ACEP) wetlands and reference wetlands located in West Virginia, USA. Percent coverage of vegetation is the response variable and ACEP or reference wetland type is the predictor. .24

Figure 1-5. Results of logistic regression conducted with wetland features or stressors as the response variable and Agricultural Conservation Easement Program (ACEP) wetland or reference wetland on presence / absence data of wetland features or stressors on ACEP and reference wetland sites located in West Virginia, USA measured in May 2017

Figure 1-6. ANOVA model results from comparison of Shannon-Weaver diversity indices of macro-invertebrates. Red point and lines represent macro-invertebrate group mean and 95\% confidence intervals on Agricultural Conservation Easement Program wetlands, blue point and lines represent macro-invertebrate group mean and 95\% confidence intervals on reference wetlands

Figure 2-1. All wetlands enrolled in the Agricultural Conservation Easement Program (ACEP) administered through the Natural Resources Conservation Service in West Virginia, USA along with reference wetlands located on public land on wildlife management areas, state parks, and The Nature Conservancy land. Blue squares represent reference sites and red circles represent ACEP wetland sites.

Figure 2-2. Placement of point count surveys to determine sparrow occupancy and species richness at wetlands in West Virginia, USA. Yellow dots represent point count locations. Red polygons represent wetland boundaries.

Figure 2-3. Nested quadrat design used to measure horizontal vegetative cover at each point location on Agricultural Conservation Easement Program (ACEP) and reference wetlands located in West Virginia, USA. Five 1x1 m quadrats were placed five $\mathrm{m}$ apart with the point count location serving as the center $1 \mathrm{x} 1 \mathrm{~m}$ quadrat. Within the $1 \mathrm{x} 1$ $\mathrm{m}$ quadrats, percent cover of herbaceous material, shrub, bare-ground, woody vegetation, and water were measured. Within the $5 \times 5 \mathrm{~m}$ quadrats, percent shrub was measured. 
Figure 2-4. Swamp sparrow and dark-eyed junco occupancy probabilities on Agricultural Conservation Easement Program (ACEP) and reference wetland sites located in West Virginia, USA obtained from detection / non-detection survey data collected in the winters of 2016-2017 and 2017-2018. Occupancy probability differed significantly between ACEP and reference sites for swamp sparrows and dark-eyed juncos. Swamp sparrow occupancy estimates are from the top swamp sparrow occupancy model that included wetland size and year, dark-eyed junco occupancy probability is from the respective top occupancy model that also included the presence of shrub at the $5 \times 5$ meter scale and wetland size.

Figure 2-5. Swamp sparrow detection probability on Agricultural Conservation Easement Program (ACEP) and reference wetland sites located in West Virginia, USA obtained from detection / non-detection survey data collected in the winters of 2016 - 2017 and 2017-2018. Detection is modeled as a function of the variables included in the top detection model: noise disturbance in decibels

.62

Figure 2-6. Swamp sparrow occupancy probability on Agricultural Conservation Easement Program (ACEP) and reference wetland sites located in West Virginia, USA obtained from detection / non-detection survey data collected in the winters of 2016 - 2017 and 2017-2018. Occupancy is modeled as a function of the variables included in the top occupancy model: wetland size in acres (top) and as a function of year (bottom).

Figure 2-7. Dark-eyed junco detection probability on Agricultural Conservation Easement Program (ACEP) and reference wetland sites located in West Virginia, USA obtained from detection / non-detection survey data collected in the winters of 2016-2017 and 2017-2018. Detection is modeled as a function of the variables included in the top detection model: sky condition on a 1-4 scale, temperature in degrees Celsius and wind speed in meters / second.

Figure 2-8. Dark-eyed junco occupancy probability on Agricultural Conservation Easement Program (ACEP) and reference wetland sites located in West Virginia, USA obtained from detection / non-detection survey data collected in the winters of 2016-2017 and 2017-2018. Occupancy is modeled as a function of the variables included in the top occupancy model: wetland size (top) and presence of shrubs at the $5 \times 5$ meter scale (bottom).

Figure 2-9. Song sparrow detection probability on Agricultural Conservation Easement Program (ACEP) and reference wetland sites located in West Virginia, USA obtained from detection / non-detection survey data collected in the winters of 2016 - 2017 and 2017-2018. Detection probability was modeled as a function of the variables included in the top detection model: wind speed in meters / second, time of day in decimal format, survey day of year and noise disturbance in decibels.

Figure 2-10. Song sparrow occupancy probability on Agricultural Conservation Easement Program (ACEP) and reference wetland sites located in West Virginia, USA obtained from detection / non-detection survey data collected in the winters of 2016-2017 and 2017-2018. Occupancy is modeled as a function of the variables included in the top occupancy model: percent coverage of bare-ground at point count locations. Bare-ground was measured as two categories: $0-50 \%$ coverage or $>50-100 \%$ coverage 
Figure 2-11. White-throated sparrow detection probability on Agricultural Conservation Easement Program (ACEP) and reference wetland sites located in West Virginia, USA obtained from detection / non-detection survey data collected in the winters of 2016-2017 and 2017-2018. Detection is modeled as a function of the variables included in the top detection model: sky condition on a 1-4 scale .68

Figure 2-12. Apparent species richness probability on Agricultural Conservation Easement Program (ACEP) and reference wetland sites located in West Virginia, USA obtained from detection / non-detection survey data collected in the winters of 2016-2017 and 2017-2018. Apparent richness is modeled as a function of the top predictor we modeled: wetland size. Apparent species richness was positively correlated with wetland size. 


\section{LIST OF TABLES}

Table 1-1. List of land-cover categories used to categorize the surrounding area around Agricultural Conservation Easement Program (ACEP) and reference wetland sites in West Virginia in May of 2017 within a $50 \mathrm{~m}$ buffer and descriptions of land-cover categories. 27

Table 1-2. Vegetative cover classes and descriptions of cover classes measured on transects conducted on Agricultural Conservation Easement Program (ACEP) and reference wetlands located in West Virginia USA in May of 2017 (Veselka and Anderson 2011). 28

Table 1-3. Daubenmire cover classes (1959) used to assess percent coverage of vegetative cover classes on transects located on Agricultural Conservation Easement Program (ACEP) wetlands and reference wetlands located in West Virginia, USA in May of 2017. Percent range mid-points were used to obtain average vegetative coverage on wetland sites for use in MANOVA to assess differences in percent cover between ACEP wetlands and reference wetlands 30

Table 1-4. Wetland features and stressors assessed on each Agricultural Conservation Easement Program (ACEP) wetland and reference wetland located in West Virginia, USA in May of 2017

Table 2-1. Detection and occupancy covariates used to model occupancy of Passerellidae sparrows on Agricultural Conservation Easement Program (ACEP) wetlands and reference wetlands located in West Virginia. Levels indicate the categories or units the covariate was measured in.

Table 2-2. Passerellidae species detected on Agricultural Conservation Easement Program (ACEP) and reference wetland sites located in West Virginia, USA obtained from detection / non-detection survey data collected in the winters of 2016 - 2017 and 2017-2018 over both survey years and total number of individuals.

71

Table 2-3. Top detection and occupancy models for song sparrow, swamp sparrow, dark-eyed junco, and whitethroated sparrow occupancy, on Agricultural Conservation Easement Program (ACEP) and reference wetland sites located in West Virginia, USA obtained from detection / non-detection survey data collected in the winters of 20162017 and 2017-2018 with top occupancy models indicated by bold type.

Table 2-4. Number of species detected standardized by number of point counts on Agricultural Conservation Easement Program (ACEP) and reference sites respectively to obtain percent of species ACEP and reference wetland sites located in West Virginia, USA obtained from detection / non-detection survey data collected in the winters of 20162017 and $2017-2018$. 


\section{INTRODUCTION}

Wetland ecosystems are unique, important sources of wildlife habitat. Their widespread loss due to drainage and development in North America has caused the creation of many programs and policies such as federal regulation through section 404 of the Clean Water Act and provisions in the 1985 and 1990 Farm Bills to discourage landowners from draining or filling wetlands for agricultural uses to try to reverse the damage done. One such program is the Agricultural Conservation Easement Program (ACEP). ACEP is administered through the Natural Resources Conservation Service (NRCS) and provides landowners with technical and financial assistance to restore passively managed wetlands on private agricultural land while providing wildlife habitat. It is important to monitor conservation practices such as ACEP to determine if the program goals of restoring functioning wetland systems while maximizing wildlife habitat and promoting biodiversity are being met. Monitoring can be accomplished by directly surveying the wildlife community on these wetlands in combination with assessing overall wetland features and vegetative characteristics.

In West Virginia, there are 24 wetlands enrolled in ACEP. Because these wetlands occur within a fragmented agricultural landscape, they provide an important source of wildlife habitat in areas typically lacking wetland ecosystems. We conducted two studies on ACEP wetlands in West Virginia and a set of reference wetlands located on public land. First, we conducted rapid assessments on wetlands in West Virginia to evaluate the differences in surrounding land-cover, vegetative cover, and wetland stressors and features between the ACEP and reference sites. We used these data to identify differences in wetland characteristics that may contribute to a wetland's ability to function as wildlife habitat. 
The second study consisted of a species richness analysis and an occupancy analysis of wintering Passerellidae (new world) sparrows to determine avian winter use of wetlands in West Virginia. We determined species richness and occupancy probabilities on ACEP and reference wetlands to evaluate ACEP wetlands as wildlife habitat as compared to other wetlands located in the state. Overall, wetland characteristics were similar between ACEP and reference wetlands with a few notable differences. ACEP wetlands had a greater proportion of pasture in the areas immediately surrounding the wetland while reference wetlands had a greater proportion of forest. Additionally, seasonal flooding was more likely to occur on ACEP wetlands. Occupancy probabilities were greater on ACEP wetlands for two sparrow species: swamp sparrows (Melospiza georgiana) and dark-eyed juncos (Junco hyemalis). Our results indicate that ACEP is a source of early successional wetland habitat in West Virginia, and enrolled wetlands have similar features to other wetlands located throughout the state. Because of this, it is important to continue and potentially expand the ACEP program. 
Chapter 1: A Comparison of Surrounding Land-cover, Vegetative Cover, Wetland Features, and Invertebrate Diversity Between Agricultural Conservation Easement Program Wetlands and Wetlands Located on Public Land in West Virginia

\begin{abstract}
In West Virginia, there are 24 conservation easement program wetlands enrolled in the Agricultural Conservation Easement Program (ACEP). These wetlands are located on private agricultural land and are passively managed. Due to their location within fragmented agricultural areas, wetlands enrolled in ACEP in West Virginia have the potential to add wildlife habitat and wetland ecosystem services in areas that are lacking these features. We assessed the ability of wetlands enrolled in ACEP in West Virginia to function similarly to other available wetland habitat in West Virginia on public land by assessing surrounding land-cover, vegetative cover, wetland features and stressors, and invertebrate diversity on 19 ACEP wetlands and 10 reference wetlands. In general our findings suggest that ACEP wetlands have similar vegetative cover, presence of features or stressors, and invertebrate diversity as reference wetlands which indicates that ACEP wetlands are able to provide similar ecosystem services and wildlife habitat as other available wildlife habitat in West Virginia. Because of this, it is important to maintain and even expand ACEP in West Virginia to continue providing a valuable source of early successional wetland habitat.
\end{abstract}

\title{
Introduction
}

Wetlands are biologically diverse and ecologically important systems globally. They provide numerous ecosystem services and functions including carbon sequestration (Zedler and Kercher 2005), water filtration (Fennessey and Craft 2011), nutrient retention (Hansson et al. 2005), flood and storm water storage (Clarkson et al. 2013), and wildlife habitat (Dahl 2011). While providing valuable ecosystem services, wetlands are also some of the most threatened 
systems. Prior to European colonization of the conterminous United States, there were over 89 million ha of wetlands nationwide (Dahl 2011). However, at the time of European settlement, wetlands were considered an obstacle to growth and were drained for agricultural and residential development. Today, remaining wetlands are often exposed to agricultural runoff and impacts from livestock grazing (Mitsch and Hernandez 2013). Due to the crucial role wetlands play in ecosystem services and habitats, conservation programs and policies have been developed to mitigate losses.

The Agricultural Conservation Easement Program (ACEP; formerly the Wetland Reserve Program) under the Natural Resources Conservation Service (NRCS) provides a mechanism to conserve wetlands on private agricultural lands. Through this program, wetlands are enhanced or restored on private land and placed under easement with the objectives of returning agricultural areas to their historic hydrologic and vegetative regimes, thus promoting wetland ecosystem services such as wildlife habitat, water filtration, and biodiversity (Personal communication, M. Oliver, USDA). ACEP provides financial and technical assistance to landowners for enhancing or restoring wetlands on their property, and restorations are typically designed to not require active management so that the easement can be self-sustaining as a wetland (Personal communication, M. Oliver, USDA). Since its inception in 1996, the Wetland Reserve Program (WRP) and ACEP has established > 500,000 ha of restored wetland habitat nationwide (Kaminski et al. 2006). In 2016, the NRCS spent approximately $\$ 345,000,000$ on technical and financial assistance for landowners restoring wetlands through ACEP (U.S. Department of Agriculture 2016).

Given the national scope of ACEP as well as the financial cost to the federal government, it is important to monitor wetlands enrolled in this conservation easement program to ensure 
these wetlands have similar characteristics to other available wetland habitat in the same regions. There are many benefits to restoring wetland habitat on private agricultural land including positive impacts on water storage and plant and wildlife biodiversity (Gleason et al. 2011). Wetlands enrolled in the Wetland Reserve Program and ACEP have the potential to intercept and store floodwater in agricultural areas that have a high volume of runoff (Gleason and Tangen 2008a). Similarly, converting agricultural areas such as cropland to wetland conservation easements was estimated to reduce soil erosion rates in the area and therefore reduce sedimentation (Gleason and Tangen 2008b).

Generally, created or restored wetlands have similar plant species composition to naturally occurring wetlands that are managed in the same way, but are at younger successional stages than established natural wetlands (De Steven and Gramling 2013, Evans-Peters et al. 2012). While Campbell et al. (2002) found higher plant species richness and vegetative coverage on naturally occurring wetlands in Pennsylvania, a comparison between wetlands created through mitigation and naturally-occurring reference wetlands in West Virginia found no difference in average coverage of plant species, and created wetlands had higher plant diversity than reference sites (Balcombe et al. 2005a). Others have similarly found that created wetlands have a greater number of plant species than older, natural wetlands (Confer and Niering 1992), perhaps due to the earlier successional stage and lack of interspecies competition of created wetlands. In the Prairie Pothole Region, wetland restoration through the Wetland Reserve Program increased native plant species richness when compared with agricultural areas that did not have a restored conservation easement (Laubhan and Gleason 2008).

Similarly, invertebrate biomass is comparable between wetlands enrolled in the WRP and actively managed public wetlands (Tapp and Webb 2015). Macroinvertebrate richness and 
diversity did not differ between wetlands created through mitigation and naturally occurring wetlands in West Virginia (Balcombe et al. 2005b). Additionally, macroinvertebrate community and diversity were similar between natural and created wetlands in Ohio (Stanczak and Keiper 2004). Alternatively, Scatolini and Zedler (1996) found higher abundances of macroinvertebrates on natural wetlands compared to younger created wetlands in California, however species composition was similar. These differences could be attributed to differing environmental factors at the site types (Scatolini and Zedler 1996).

It is possible that agricultural areas around wetlands restored through ACEP could negatively influence the vegetation and macroinvertebrate community present on these sites. Agricultural land-cover negatively impacted wetland vegetative quality based on a floristic index, which could be attributed to agricultural runoff and pollution (Stapanian et al. 2018). However, wetlands that were impacted by factors such as cattle grazing and mowing had higher macroinvertebrate richness and diversity in a study in Nebraska (Davis and Bidwell 2008). In another study, a comparison between macroinvertebrate assemblages in conservation easement wetlands along an agricultural gradient found no significant difference between sites impacted by agriculture and those that were not impacted in the Prairie Pothole Region (Gleason and Rooney 2017). Similarities between vegetative structure and wildlife food resources such as macroinvertebrates on created or restored wetlands and reference wetland sites can promote similar species communities. Red spotted newt (Notophthalmus viridecsens) diets' compared between natural and created wetlands did not differ significantly between mitigated and reference sites (Strain et al. 2014), indicating that created and natural sites were equally able to provide wildlife food resources. Mitigated wetlands also had similar avian species richness, diversity, and abundance to reference wetlands, with waterbird abundance higher on mitigation 
sites in West Virginia (Balcombe et al. 2005c). Additionally, litter decomposition (Gingerich and Anderson 2011), and occupancy of anurans (Strain et al. 2016), were similar between mitigated and reference wetlands in West Virginia.

Whether a wetland is actively or passively managed can also impact the vegetative and wildlife characteristics of a site regardless of its status as a restored conservation easement. Active wetland management entails manipulating water levels to encourage moist-soil seed production for waterfowl and other wildlife use (Nelms 2007). Past studies that have compared wetlands between conservation easements and reference sites often include a comparison between active and passive management (Kaminski 2006, O'Neal et al. 2008, Tapp and Webb 2015). Passively managed or unmanaged wetlands can be dominated by invasive plant species that reduce biodiversity and are inadequate food resources for waterfowl (Evans-Peters et al. 2012). Actively managed wetland sites in the Mississippi Alluvial Valley had higher seed biomass than passively managed sites (Olmstead et al. 2013). In Texas playa wetlands, invertebrate and seed biomass and invertebrate diversity were higher in managed versus unmanaged wetlands (Anderson and Smith 1998, Anderson and Smith 2000). Possibly as a result of increased food resources on managed wetlands, waterfowl density and use on managed wetlands tends to be higher when compared with unmanaged (Fleming et al. 2015, Kaminski et al. 2006, O'Neal et al. 2008). Wetlands enrolled in ACEP are designed to require little ongoing maintenance once they are restored, therefore in West Virginia they are passively managed to eliminate costs to the landowner. Because of this passive management, ACEP wetlands could be more susceptible to invasive plant establishment without active invasive species control (Smith et al. 2016, Peralta et al. 2017).

Currently, there are 24 wetlands enrolled in ACEP in West Virginia totaling 179 ha. 
These West Virginia ACEP wetlands have the potential to provide wildlife habitat within a fragmented, agriculturally dominated landscape. However their ability to do so has never been evaluated. Previous research evaluating specific wetland characteristics in West Virginia has focused on wetlands created through mitigation, or has occurred on a small subsample of ACEP sites (Balcombe et al. 2005a, 2005b, 2005c, Clipp et al. 2017, Strain et al. 2014). Additionally, past wetland research has compared actively and passively managed wetlands (Anderson and Smith 1998, Anderson and Smith 2000, Fleming et al. 2015, Kaminski et al. 2006, O’Neal et al. 2008) but most ACEP wetlands in West Virginia are passively managed. We conducted a statewide assessment of multiple wetland features on ACEP and reference wetlands to determine if ACEP wetlands were meeting the broad ACEP objectives of restoring wetland ecosystems on agricultural land while maximizing wildlife habitat and evaluate how ACEP wetlands compare to other wetlands in West Virginia.

Our objectives were to compare physical and biological characteristics of ACEP conservation easement wetlands in West Virginia with nearby reference wetlands. Specifically, we compared the immediate surrounding landscape land-use, vegetative coverage, presence of general features, and invertebrate diversity on each site. We used these data to (a) determine if ACEP wetlands are meeting program objectives, and (b) evaluate whether ACEP wetlands have similar characteristics to other wetlands throughout West Virginia. We hypothesized that ACEP wetland characteristics overall would be similar to reference wetlands and function similarly to other available wetlands located in the state.

\section{Study Area}

We conducted assessments of ACEP and reference wetland characteristics in West Virginia in May of 2017. This study occurred on 19 ACEP and 10 reference wetlands located in 
17 counties in West Virginia (Figure 1). West Virginia is a predominantly mountainous, forested state: approximately $80 \%$ of West Virginia is forested (Morin et al. 2017), while $<1 \%$ of the state's surface is covered by wetlands (Tiner et al. 1994). West Virginia is composed of several physiographic provinces. The wetland sites included in this study were located within the Appalachian Plateau, Allegheny Mountain Section, Valley and Ridge, and the Great Valley physiographic provinces (West Virginia Geological and Economic Survey 2017).

We included all West Virginia wetlands enrolled in ACEP with the exception of five sites where we were denied access by the landowners. Wetlands ranged in size from $<0.4$ ha to 32 ha. All wetlands were classed as either palustrine emergent, forested, or scrub-shrub wetlands (Cowardin et al. 1979). Emergent wetlands were dominated by rooted hydrophytic vegetation such as cattails (Typha spp.), bulrush (Scirpus spp.), and sedges (Carex spp.). Forested wetlands had an over-story of trees and were dominated by woody vegetation $>6$ meters tall. Scrub-shrub wetlands were dominated by woody vegetation $<6$ meters tall such as alders (Alnus spp.) and buttonbush (Cephalanthus occidentalis) (Cowardin et al. 1979). The ACEP wetland sites were located on private land with the exception of one site located on a wildlife management area within an agricultural landscape dominated by hay, corn, or pasture cover. Wetlands were restored through ACEP between 1996 and 2012 (Appendix A). Reference wetlands were located on public land in wildlife management areas, state parks, national forests, or property owned by The Nature Conservancy. These sites had a similar size distribution $(\leq 32$ ha) to ACEP sites, were of the same wetland classes of palustrine emergent, forested, or scrub-shrub, and were located in the same or adjacent counties to ACEP wetlands. 


\section{Methods}

\section{Reference Site Selection}

We selected reference sites from publicly accessible wetlands in close proximity to ACEP wetlands. We used the National Wetlands Inventory data layer (US Fish and Wildlife Service 2016) to identify wetlands in WV wildlife management Areas, WV state parks, WV state forests, and property owned by The Nature Conservancy. We then limited this list to include only wetlands that were $\leq 32$ ha; classified as emergent, scrub-shrub, or forested; and in the same or an adjacent county as ACEP wetlands. We conducted our assessments on 10 reference wetlands randomly selected from a group of 13 potential reference sites.

\section{Wetland Characteristics Assessments}

We measured the vegetative characteristics and presence or absence of wetland-related features and stressors by conducting assessments of different wetland characteristics based on the West Virginia Wetland Rapid Assessment Procedure training manual (Veselka and Anderson 2011) during May of 2017. Functional assessments included a $50 \mathrm{~m}$ buffer zone characterization of land immediately adjacent to each wetland, vegetative transects within each wetland, and an assessment of the presence or absence of a set of wetland features and stressors. We also indexed macroinvertebrate diversity on ACEP and reference wetlands, which we describe in detail below.

We visually characterized land-cover within $50 \mathrm{~m}$ around each wetland site. We classified dominant land-cover into 6 categories describing the principle use of the land (Table 1). We determined dominant land-cover type by further diving the $50 \mathrm{~m}$ buffer into five $10 \mathrm{~m}$ buffers (Figure 2). We then walked the perimeter of each wetland site and visually characterized the dominant land-cover within each 10 m increment (Veselka and Anderson 2011: 10). 
To characterize vegetative conditions and the presence or absence of wetland features and stressors within wetlands we evaluated 11 different vegetative characteristics (Table 2), recording a Daubenmire cover-class category (Daubenmire 1959) for each characteristic (Table 3). We evaluated the vegetative characteristics on $50 \mathrm{~m}$ transects that we placed perpendicular to the flow of water within each wetland (Figure 2). We included one transect per 0.6 ha, spaced 78 $\mathrm{m}$ apart. Each transect was further subdivided into $10 \mathrm{~m}$ increments, and we characterized the percent coverage of vegetative cover classes at each increment. After completing each transect, we recorded the presence or absence of several wetland features and stressors along each transect (Table 4).

To document invertebrate communities on the wetland sites, we took 20 soil core samples to a depth of $20 \mathrm{~cm}$ on each wetland using a $5 \mathrm{~cm}$ diameter core sampler. We spaced core sampling locations approximately evenly around standing water features. For sites that had more than one water feature, we divided the number of core samples approximately evenly between each water feature. If the wetland had no standing water, we took 20 core samples evenly along transects. In the lab, we washed each soil core sample through a size 35 (500 $\mu \mathrm{m}$ mesh-size) sieve (Advantech Manufacturing) to find and identify macroinvertebrates (Cheal et al. 1993, Entrekin et al. 2007). We identified invertebrates to Family (Kellogg 1994, WV Department of Environmental Protection 2018).

\section{Statistical Analyses}

We compared buffer area land-cover and vegetative characteristics between ACEP and reference sites with multivariate analysis of variance (MANOVA) $(\alpha=0.05)$. Because our data consisted of percentages that represented different categories of cover classes, our data did not meet the normality assumption of MANOVA. However, MANOVA is robust enough to account 
for non-normality in ecological data (Glass et al. 1972, McDonald 2014). For the land-cover analysis, our response variable was the proportion of buffers that were classified as each landcover category, and our predictor variable was the wetland type: either ACEP or reference. For our vegetative characteristics analysis, our response was the average Daubenmire midpoints of each cover class over all transects at each site (Daubenmire 1959). We then ran individual contrasts using emmeans version 1.1.3 (Lenth et al. 2018) with program R version 3.3.1 (R Core Team 2016) to calculate the group means, differences between group means, and statistical significance of the differences between group means of each variable on ACEP and reference sites. We compared the probability that a wetland feature or stressor was present at ACEP or reference wetlands with logistic regression at the wetland site scale. Our response was the presence or absence of the wetland stressors or features, our predictors were the ACEP or reference wetland type.

We calculated macroinvertebrate diversity at each wetland site with the Shannon-Weaver diversity index (Shannon and Weaver 1949). We calculated the diversity index with the diversity() function in package "vegan" version 2.4-6 (Oksanen et al. 2018) within program R version 3.3.1 (R Core Team 2016). We assessed macroinvertebrate diversity associations with each of the wetland site types, ACEP or reference, using analysis of variance (ANOVA) $(\alpha=0.05)$ to determine if macroinvertebrate community assemblages differed between ACEP and reference sites.

\section{Results}

We conducted wetland characteristics assessments with 44 transects on 10 reference wetlands $(\overline{\mathrm{x}}=4, \mathrm{se}=0.85, \min =1, \max =10)$ and 132 transects on 19 ACEP wetlands $(\overline{\mathrm{x}}=7$, $\mathrm{se}=1.08, \min =1, \max =21)$. ACEP and reference sites differed in dominant land-cover 
surrounding wetlands. The predominant land-cover surrounding all sites was the forest landcover type (ACEP $\bar{x}=0.11, \mathrm{se}=0.06$, reference $\bar{x}=0.54, \mathrm{se}=0.08)$, followed by the pasture landcover type (ACEP $\bar{x}=0.55$ se $=0.07$, reference $\bar{x}=0.08$, se $=0.10$ ). The proportion of pasture was higher in the ACEP buffer zones $\left(\mathrm{t}_{26}=3.79, \mathrm{p}<0.001\right)$, and the proportion of forest was higher in the reference buffer zones $\left(\mathrm{t}_{26}=-4.06, \mathrm{p}<0.001\right)$ (Figure 3 ). The other land-cover category proportions did not differ between ACEP and reference sites (Figure 3). The predominant vegetation on all sites was emergent vegetation $($ ACEP $\bar{x}=26.1 \%$, se $=6.20$, reference $\bar{x}=44.5 \%$, se=8.50), followed by broad-leaved deciduous shrubs (ACEP $\bar{x}=25.7 \%$, se $=7.22$, reference $\overline{\mathrm{x}}=44.0 \%$, se $=9.93$ ). Though the dominant vegetation was largely similar between sites, we detected slight differences in vegetative cover within wetlands. Percentage of invasive herbaceous material was higher on reference sites than on ACEP sites $(\mathrm{ACEP} \overline{\mathrm{x}}=3.61 \%$, se $=$ 1.22 , reference $\overline{\mathrm{x}}=8.68 \%$, se $=1.68)\left(\mathrm{t}_{24}=-2.44, \mathrm{p}<0.05\right)$, but all other vegetative cover classes were not significantly different between ACEP and reference sites (Figure 4).

The presence of wetland features such as saturated ground, upland inclusion, and stream channels were present on the majority of both ACEP and reference sites. One wetland feature, seasonal flooding, differed between ACEP and reference sites, and none of the wetland stressors included in the study differed significantly between sites. ACEP wetlands were more likely to have seasonal flooding $(\mathrm{z}=2.35, \mathrm{p}<0.05)$ (Figure 5).

We detected 6 families of invertebrates (Appendix B). Enchytraeidae $(n=28)$, Prosobrachia $(n=18)$, and Tabanidae $(n=16)$ were the most abundant families we found in samples across reference and ACEP sites. Out of all of the sites, one ACEP site had a diversity index higher than zero, and one reference site had a diversity index higher than zero (Appendix 
B). The Shannon-Weaver diversity index was not significantly different between ACEP and reference sites $(\mathrm{F}=0.434, \mathrm{p}>0.05)$ (Figure 6).

\section{Discussion}

We found that ACEP wetlands were generally similar in terms of vegetative structure and invertebrate communities to wetlands located on public land. Similar characteristics such as vegetative cover on ACEP wetlands to wetlands on public land indicates that ACEP wetlands are able to filter water and provide wildlife habitat similarly to other wetlands located in the state. The root systems of hydrophytic vegetation such as emergent plants can contribute to a wetland's ability to filter water as it moves through the wetland (Coleman et al. 2000). Additionally, the presence of shrubs or dense herbaceous material can provide wildlife shelter. Dabbling duck use of wetlands was positively correlated with dense emergent vegetation (Osborn et al. 2017), as it provides thermal cover in the winter (Jorde et al. 1984) and possible shielding from predation (Euliss and Harris 1987) in addition to acting as a food resource in the form of seeds and tubers. Vegetative cover is also directly important to avian species during the breeding season as it provides nesting material and breeding shelter (Lopez-Pomares et al. 2015). Because the ACEP wetlands included in this study are located on private agricultural land that was previously pasture or cropland, this program is a source of early successional wetlands and associated ecosystem services that would otherwise not be present on the agricultural fields these wetlands are restored on.

We did find some features differed between ACEP and reference sites. Most notably, ACEP sites had higher proportions of pasture within a $50 \mathrm{~m}$ buffer around the wetland edge, while reference wetlands had higher proportions of forest within a $50 \mathrm{~m}$ buffer around the 
wetland edge. Given that ACEP is focused on the conservation of wetlands on agricultural lands, and ACEP wetlands were located directly on agricultural fields, these findings are not surprising. The lack of differences we detected in terms of other characteristics such as vegetative cover and macroinvertebrate diversity between wetlands located on agricultural land and wetlands not located on agricultural land is supported by past studies that evaluated differences in plant community and invertebrate diversity or biomass on agricultural land or conservation easement wetlands (Confer and Niering 1992, Gleason et al. 2011, Gleason and Rooney 2017, Laubhan and Gleason 2008, Tapp and Webb 2015). Therefore, it appears that the immediate surrounding land-cover of these sites did not impact the characteristics of the wetlands themselves, although further study on a finer scale may be necessary to determine differences between sites that we did not measure.

While the immediate surrounding forested areas of reference sites or agricultural land of ACEP sites did not drastically influence the characteristics of the wetlands themselves, the habitat heterogeneity associated with wetlands located on open fields along with shrub and tree lines can contribute to the wildlife habitat it provides. Wintering new world sparrows were more likely to be found on ACEP wetlands over reference wetlands in a concurrent study, which could be attributed to a higher level of habitat heterogeneity associated with the location of ACEP sites (Lewis, Chapter 2). ACEP wetlands may be a source of unique wetland habitat within West Virginia due to their location on agricultural land, which is in contrast to the landscape surrounding reference wetlands.

Despite the potential for the areas immediately surrounding wetlands to influence wetland features and vegetative characteristics (Veselka and Anderson 2011), we only found a significant difference in the percentage of invasive herbaceous material such as reed canary grass 
(Phalaris arundinacea) between ACEP and reference sites. The higher percentage of invasive herbaceous material on reference sites compared to ACEP wetlands is contrary to what others have found in the past. Studies comparing the vegetative community on restored and reference wetlands in both the southeast region of the United States and in Oregon and Washington found no difference in plant community composition between sites (Balcombe et al. 2005a, De Steven and Gramling 2013, Evans-Peters et al. 2012). However, studies in the southeast United States evaluating conservation easement wetland vegetative communities support our findings that ACEP wetlands have predominantly native wetland vegetation (De Steven and Gramling 2012, De Steven and Gramling 2013). New wetlands that are passively managed could be more susceptible to colonization by invasive clonal graminoids that are difficult to eradicate (Rojas and Zedler 2015). However, the ACEP sites included in this study were planted with native species at the time of restoration, so invasive species would not have become as easily established. Alternatively, ACEP wetland restoration occurs in agricultural areas that are typically isolated from other wetland habitat. Therefore, the surrounding areas lack invasive wetland plants so invasive herbaceous species may not colonize the ACEP sites. Reference wetlands were publically accessible, and were potentially more susceptible to invasive species establishment due to propagule dispersal through unintentional human transport (Brancatelli and Zalba 2018). Another invasive wetland plant, common reed (Phragmites australis), was more likely to be found in areas close to point source pollution (Long et al. 2017), which indicates that invasive wetland plants can tolerate less-pristine conditions that may exist on the publically accessible reference wetlands included in this study.

Although ACEP wetlands are largely similar to reference sites in vegetative cover, having lower percentages of invasive herbaceous material may increase their value as wildlife 
habitat. Wildlife that are dependent on wetland habitat throughout their annual cycle such as anurans can be negatively impacted by invasive herbaceous material because it can reduce native plants that act as food and cover (Brown et al. 2006). The reproductive success of specialist avian species that rely on specific native wetland vegetation or vegetative diversity for nesting can also be negatively impacted by invasive wetland plants (Lupien et al. 2015). The amount of invasive herbaceous material on a wetland during the breeding season could carry over into winter habitat selection, which we measured in terms of higher occupancy of Passerellidae species on ACEP wetland sites relative to reference sites (Lewis, Chapter 2). Other invasive wetland plants such as common reed can reduce suitable breeding habitat for other wetland wildlife such as turtles. Common reed can overtake a wetland system and shade nesting areas that require certain temperatures to be successful (Bolton and Brooks 2010). Alternatively, some invasive wetland plants may have differential effects on wildlife as their presence could provide nesting or hiding cover for generalist species. Wetland specialists such as marsh wrens (Cistothorous palustris) that nest in cattail marshes were negatively associated with shrubby purple loosetrife (Lythrum salicaria) while Virginia rails (Rallus limicola) were positively associated with the dense hiding cover provided by the plant (Tavernia and Reed 2012).

We also only found significant differences in one of the wetland features and stressors that we measured. Seasonal flooding was more likely to occur on ACEP wetlands. This could be due to the nature of where ACEP wetlands are located. To restore a sustainable wetland, a source of water such as a stream, periodic flooding, or permanent flooding due to depressions is important. While our reference wetlands also had standing water features, this was usually in the form of a large lake or permanent stream that were not present due to flooding. ACEP wetlands in this study may be more likely to have seasonal flooding because they are isolated from other 
wetland complexes or permanent sources of water. Past studies in the Prairie Pothole Region found that conservation easement wetlands were isolated from wetland complexes, and overrepresented the historical number of seasonal wetlands (Galatowitsch and van der Valk, 1996). The presence of seasonal flooding on ACEP wetlands indicates that the restored wetlands are returning to and maintaining hydrological regimes that may have been present before agricultural development.

Our macroinvertebrate individual counts and diversity indices were lower than other studies evaluating similar metrics (Hall et al. 2004), which could be attributed to the limited time period during which this study occurred or the smaller sample size of sites we evaluated than other studies. Possibly because other wetland characteristics such as vegetative structure were similar between sites, macroinvertebrate diversity did not differ significantly between sites. De Szalay and Resh (2000) found that macroinvertebrate diversity was greater with increased emergent vegetation on wetland treatments in California. Macroinvertebrate diversity on our sites may not have differed due to the similar vegetative coverage across site types. The lack of macroinvertebrate diversity differences between restored and natural wetlands in our study is supported by past studies (Balcombe et al. 2005b, Stanczak and Keiper 2004). Other features such as the amount of leaf litter and detritus located on a wetland due to disking, mowing, and moist soil management are important for invertebrate production (Nelson et al. 1990, Tapp and Webb 2015). Neither our ACEP nor our reference sites had a significant amount of mowing or vegetation alteration present. Our invertebrate numbers were low across both site types, possibly because of a lack of litter or detritus. Additionally, the wetlands included in our study were mostly passively managed. Invertebrate metrics such as density, biomass and diversity can increase with moist soil seed production management (Anderson and Smith 2000). It is also 
possible that the use of insecticides and neonicotinoids in the areas surrounding our wetland sites impacted macroinvertebrate prevalence. Several macroinvertebrate families are sensitive to pesticides used in farming practices (Morrissey et al. 2015, Rico and Van Den Brink 2015). Further study of specific aquatic pollution present on these sites is required to fully evaluate the impacts this may have on macroinvertebrate diversity and counts. This has implications for these wetlands to provide food resources to wildlife such as waterfowl. Invertebrates are a source of protein for wintering waterfowl species (Anderson and Smith 1998). However, agricultural lands and vegetation based food resources have increasingly become a larger part of waterfowl diet (English et al. 2017). Therefore, wetlands enrolled in ACEP may still be suitable waterfowl wildlife habitat despite their lack of macroinvertebrates.

Our findings suggest that wetlands restored through ACEP that occur on private, agricultural land and are passively managed are mostly similar in terms of vegetative communities, wetland features, lack of stressors, and invertebrate diversity to wetlands located on public lands. We detected a few important differences between site types that have positive implications for ACEP wetlands in terms of their ability to provide wildlife habitat. Their lack of invasive herbaceous material relative to reference wetlands means these wetlands are a source of unique habitat.

ACEP wetlands provide early successional wetland habitats within an agricultural landscape matrix. In conjunction with the wildlife habitat provided by reference wetlands located on public land in forested areas, these wetlands are an important component of wildlife habitat, as they exist within a diverse landscape that frequently consists of farm fields, forested and shrubby field edges, and wetland habitat, thus appealing to a variety of species. The slight differences we found on ACEP wetlands highlights the importance of continuing and expanding 
ACEP in West Virginia. According to our results, this program is providing functional wetland ecosystems in areas that were historically wetlands but were developed for agricultural purposes. ACEP creates a system in West Virginia to restore wetlands in areas that lost these habitat features due to agricultural development. Additionally, because we detected some differences between site types the combination of ACEP wetlands with other wetlands located in West Virginia provides a diversity of wetland ecosystems that could promote wetland biodiversity on a state-wide scale. 


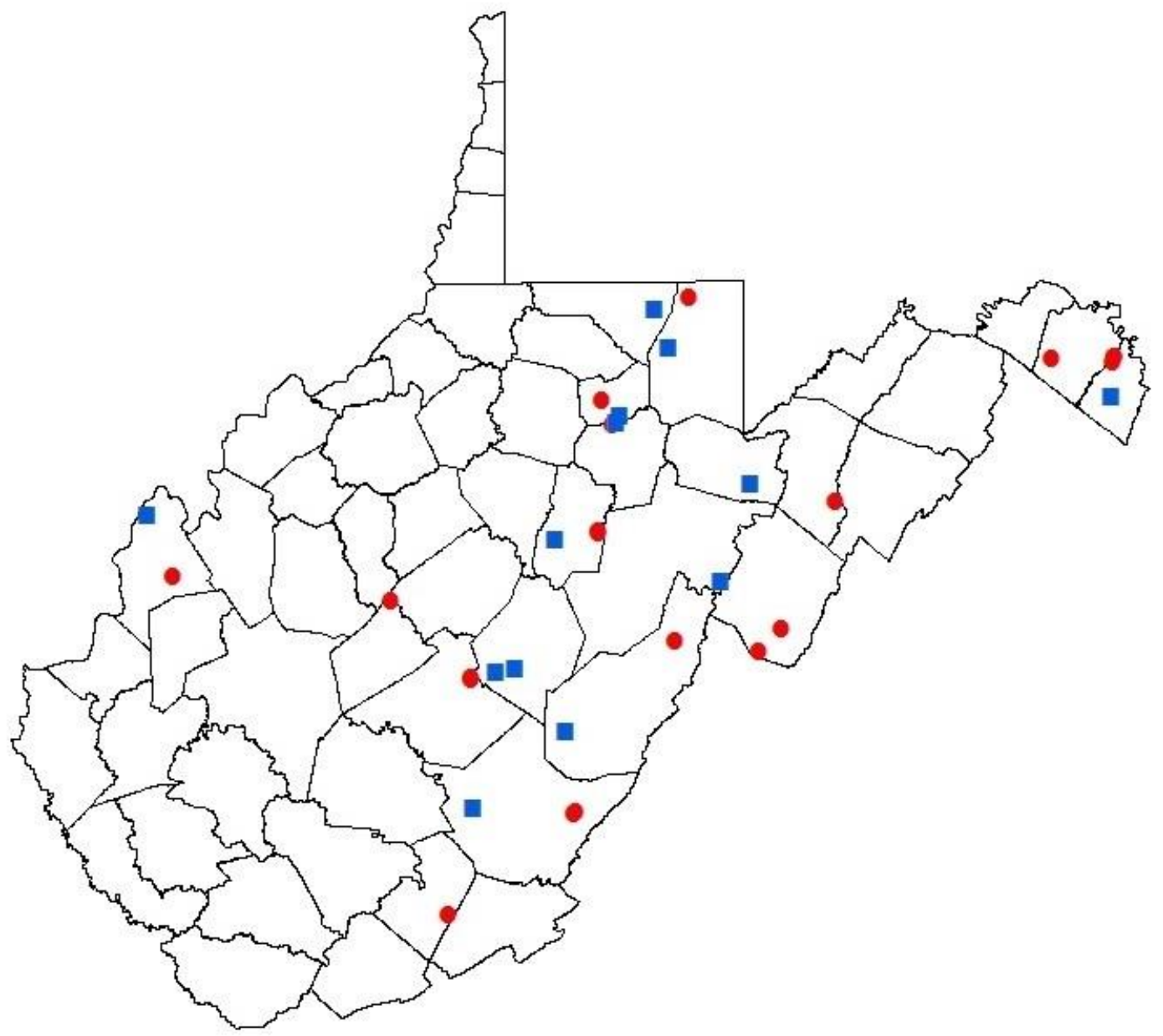

- Reference

- $\quad$ ACEP

Figure 1. All wetlands enrolled in the Agricultural Conservation Easement Program (ACEP) administered through the Natural Resources Conservation Service in West Virginia, USA along with reference wetlands located on public land on wildlife management areas, state parks, and The Nature Conservancy land. Blue squares represent reference sites and red circles represent ACEP wetland sites. 


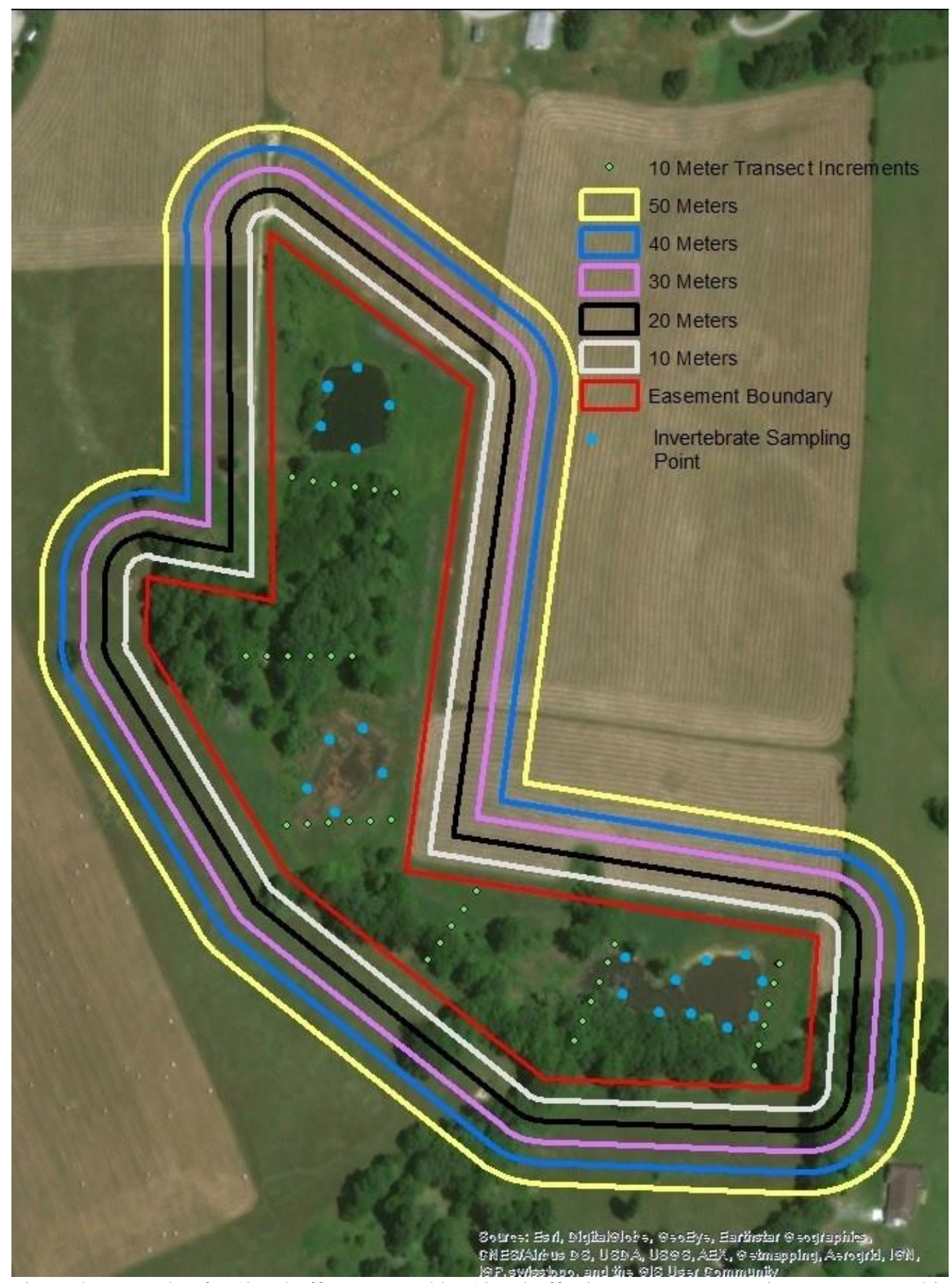

Figure 2. Example of a $50 \mathrm{~m}$ buffer separated by $10 \mathrm{~m}$ buffer increments, vegetative transects, and invertebrate sampling locations around an Agricultural Conservation Easement Program wetland site in West Virginia, USA. Red represents the wetland easement boundary. Transects are placed every $78 \mathrm{~m}$, are $50 \mathrm{~m}$ long and are broken into $10 \mathrm{~m}$ increments represented by green dots. Blue dots represent invertebrate sampling locations which were placed approximately evenly around water features and distributed evenly across water features. 


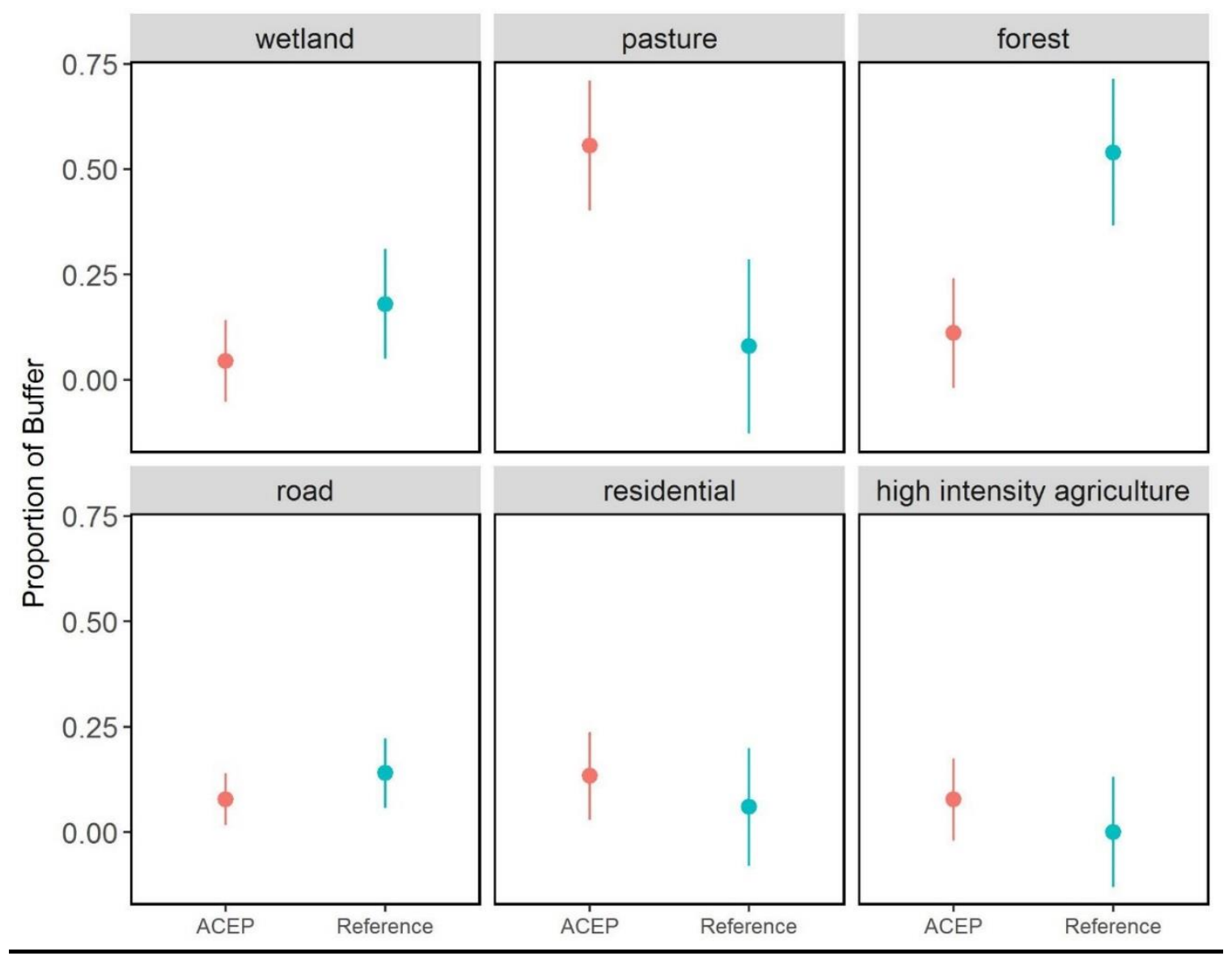

Figure 3. Results of MANOVA analysis conducted on the proportion of land-cover surrounding Agricultural Conservation Easement Program (ACEP) and reference wetlands in West Virginia, USA conducted in May 2017 with land cover category proportions as the response variable and ACEP or reference wetland type as the predictor. Results broken down by the six land-cover categories observed in the $50 \mathrm{~m}$ buffers with $95 \%$ confidence intervals. 

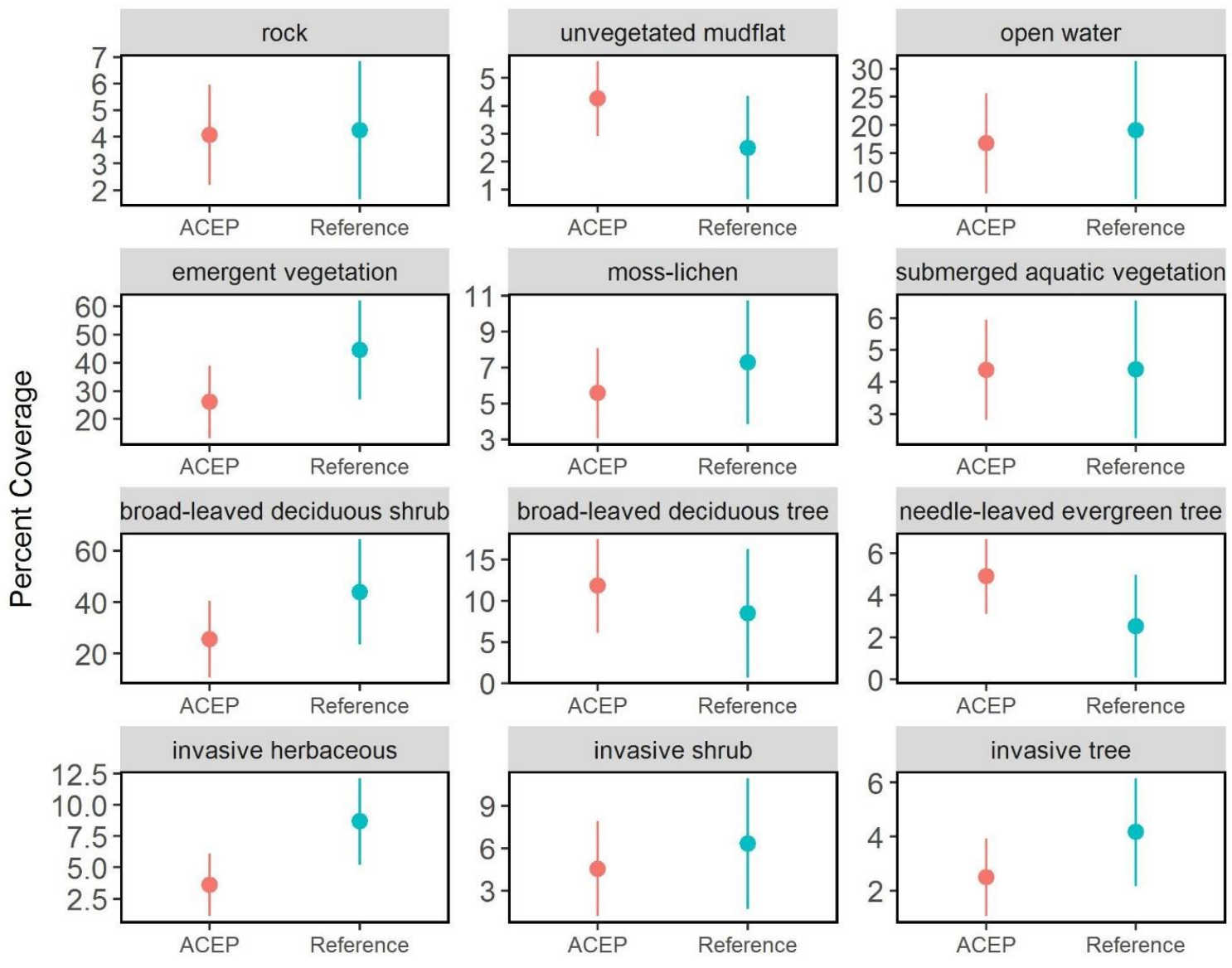

Figure4. Results of MANOVA analysis conducted on percent coverage of vegetative categories recorded on transects in May of 2017 on Agricultural Conservation Easement Program (ACEP) wetlands and reference wetlands located in West Virginia, USA. Percent coverage of vegetation is the response variable and ACEP or reference wetland type is the predictor. 


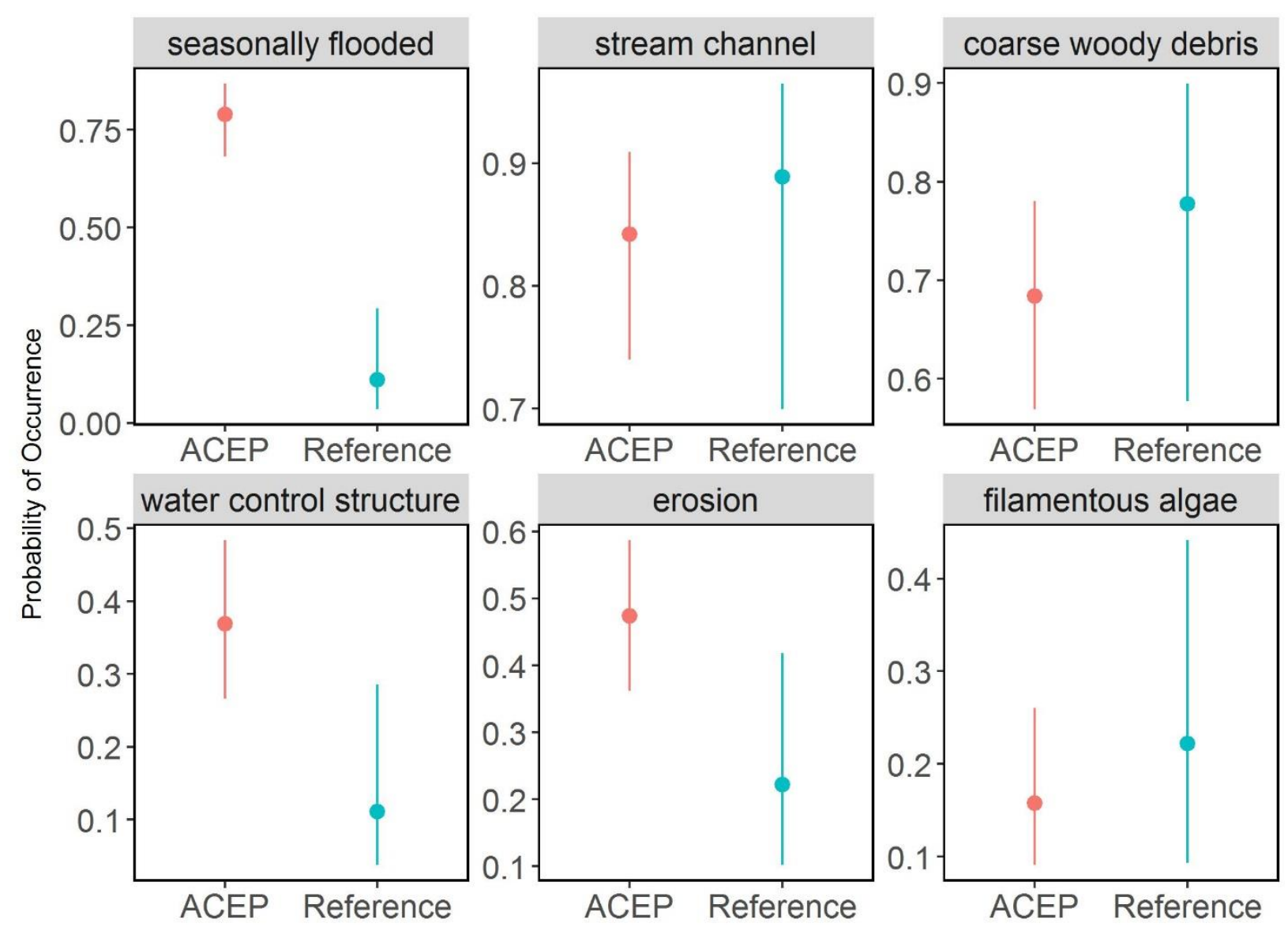

Figure 5. Results of logistic regression conducted with wetland features or stressors as the response variable and Agricultural Conservation Easement Program (ACEP) wetland or reference wetland on presence / absence data of wetland features or stressors on ACEP and reference wetland sites located in West Virginia, USA measured in May 2017. 


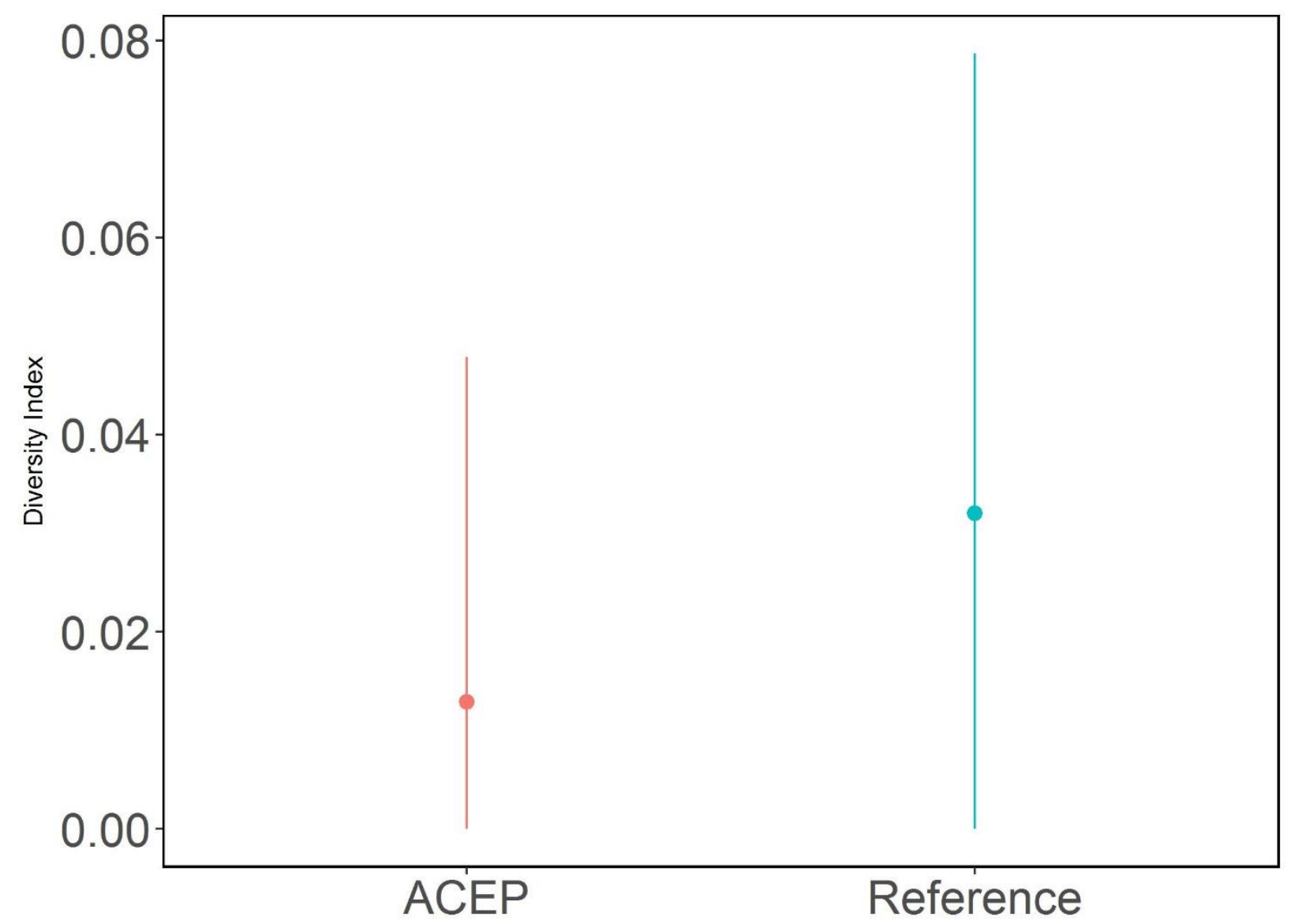

Figure 6. ANOVA model results from comparison of Shannon-Weaver diversity indices of macroinvertebrate families. Red point and lines represent macroinvertebrate group mean and 95\% confidence intervals on Agricultural Conservation Easement Program wetlands, blue point and lines represent macro-invertebrate group mean and 95\% confidence intervals on reference wetlands located in West Virginia, USA 
Table 1. List of land-cover categories used to categorize the surrounding area around Agricultural Conservation Easement Program (ACEP) and reference wetland sites in West Virginia in May of 2017 within a $50 \mathrm{~m}$ buffer and descriptions of land-cover categories

Land-Cover Buffer Category Description

Forested

Wetland

Roads

Pasture

Residential

High Intensity Agriculture
Dominated by tree stands, $>50 \%$ tree coverage

Standing water or other wetland types (e.g., scrub shrub, emergent) that extends beyond the ACEP easement boundary.

1 or 2 lane paved roads, low-use recreational roads such as gravel paths

Mowed fields or fields used by livestock

Single family homes, apartments, townhouses

Dairy farm operations that include cattle feed lots, impervious surfaces such as milking parlors, and unvegetated cattle enclosures 
Table 2. Vegetative cover classes and descriptions of cover classes measured on transects conducted on Agricultural Conservation Easement Program (ACEP) and reference wetlands located in West Virginia USA in May of 2017 (Cowardin et al. 1979, Veselka and Anderson 2011)

Transect Vegetation Cover Classes Description of Cover Classes

Rock Bare rock

Unvegetated mud flat

Open water

Emergent vegetation

Moss / lichen

Submerged aquatic vegetation

Shrub: Broad-leaved deciduous

Tree Canopy: Broad-leaved deciduous

Tree Canopy: Needle-leaved evergreen

Invasive herbaceous
Areas along the shoreline of water features, areas of wet soil that do not have any plant growth

Ponds, streams, or areas where water is deep enough to obscure any vegetation

Rooted hydrophytic vegetation such as Typha, Carex spp.

Mosses or lichens

Rooted vascular vegetation completely submerged in water such as Potamogeton spp.

Shrubs that lose leaves yearly such as buttonbush (Cephalanthus occidentalis)

Broad-leaved trees that lose their leaves yearly such as oaks (Quercus spp.) and maples (Acer spp.)

Needle-leaved trees that retain their needles throughout the year such as pines (Pinus spp.) and firs (Abies spp.)

Non-native grass or forb such as reed canary grass (Phalaris arundinacea) and Phragmites (Phragmites australis) 
Invasive shrub

Invasive tree
Non-native shrub ( $<6$ meters tall) such as multiflora rose (Rosa multiflora), honeysuckle bush (Lonicera spp.), and

Non-native tree ( $>6$ meters tall) such as autumn olive (Elaeagnus umbellata) and tree of heaven (Ailanthus altissima) 
Table 3. Daubenmire cover classes (1959) used to assess percent coverage of vegetative cover classes on transects located on Agricultural Conservation Easement Program (ACEP) wetlands and reference wetlands located in West Virginia, USA in May of 2017. Percent range mid-points were used to obtain average vegetative coverage on wetland sites for use in MANOVA to assess differences in percent cover between ACEP wetlands and reference wetlands

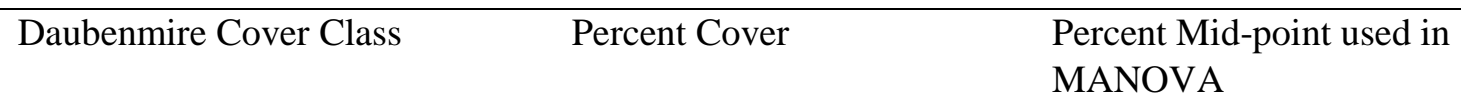

1

$\begin{array}{ll}0-5 & 2.5\end{array}$

2

$5-25$

15

3

$25-50$

37.5

4

50-75

62.5

5

75-95

85 
Table 4. Wetland features and stressors assessed on each Agricultural Conservation Easement Program (ACEP) wetland and reference wetland located in West Virginia, USA in May of 2017

Wetland feature and stressor presence/absence variables Description of variables (Anderson and Veselka 2011, pg. 28-38

\begin{tabular}{ll}
\hline Upland inclusion & $\begin{array}{l}\text { Upland vegetation / lack of hydrology } \\
\text { present }\end{array}$
\end{tabular}

Stream channel

Any stream flowing through the wetland

Entrenched stream channel

A stream channel that is not connected to the surrounding wetland and has eroding banks or slopes

Permanently flooded

Surface water appears to be present throughout the entire year

Seasonally flooded

Surface water is present only during a portion of the year

Saturated soil

Soil is saturated to the surface, but not flooded

Eroding banks or slopes

Stream banks or slopes displaying sloughing indicative of erosion

Chemical / agricultural spills and odors

Odors or spills indicating pollution from agricultural or chemical sources

Vegetated mound

Soil mounds indicating digging or construction that have vegetation

Coarse woody debris

Dead woody vegetation such as logs or stumps

Standing snags

Dead woody vegetation that is upright and $>6$ meters tall

No surface water inlet/outlet

Indicates isolated wetland that is artificially flooded

\begin{tabular}{ll}
\hline Relatively non-permanent waterway & $\begin{array}{l}\text { A channel or stream that is not consistent } \\
\text { and only occurs after precipitation or } \\
\text { flooding }\end{array}$ \\
\hline Water control structure & $\begin{array}{l}\text { Spillway or dam that controls the flow of } \\
\text { water into and out of the wetland }\end{array}$ \\
\hline Dead/dying vegetation due to hydrology & $\begin{array}{l}\text { Water stressed vegetation that is identified } \\
\text { by water levels }\end{array}$
\end{tabular}


Filamentous algae

Algae that can occur in algal mats and could indicate eutrophication from agricultural runoff

Submerged rooted vascular vegetation

An indication that recent flooding has occurred through rooted vegetation submerged under the water or partially sticking up out of the water 


\section{Literature Cited}

Anderson, J.T., and L.M. Smith. 1998. Protein and energy production in Playas: implications for migratory bird management. Wetlands. 18(3): 437-446.

Anderson, J.T. and L.M. Smith. 2000. Invertebrate response to moist-soil management of playa wetlands. Ecological Applications. 10(2): 550-558.

Balcombe, C.K., J.T. Anderson, R.H. Fortney, J.S. Rentch, W.N. Grafton,W.S. Kordek. 2005a. A comparison of plant communities in mitigation and reference wetlands in the MidAppalachians. Wetlands. 25(1): 130-142.

Balcombe, C.K., J.T. Anderson, R.H. Fortney, W.S. Kordek. 2005b. Aquatic macroinvertebrate assemblages in mitigated and natural wetlands. Hydrobiologia. 541: 175-188.

Balcombe, C.K., J.T. Anderson, R.H. Fortney, W.S. Kordek. 2005c. Wildlife use of mitigation and reference wetlands in West Virginia. Ecological Engineering. 25: 85-99.

Bolton, R.M., and R.J. Brooks. 2010. Impact of the seasonal invasion of Phragmites australis (common reed) on turtle reproductive success. Chelonian Conservation and Biology. 9(2): 238243.

Brancatelli, G.I.E., and S.M. Zalba. 2018. Vector analysis: a tool for preventing the introduction of invasive alien species into protected areas. Nature conservation. 24: 43-63.

Brown, C.J., B. Blossey, J.C. Maerz, S.J. Joule. 2006. Invasive plant and experimental venue impact tadpole performance. Biological Invasions. 8(2):327-338.

Campbell, D.A., C.A. Cole, R.P. Brooks. 2002. A comparison of created and natural wetlands in Pennsylvania, USA. Wetlands Ecology and Management. 10:41-49. 
Cheal, F., J.A. Davis, J.E. Growns, J.S. Bradley, F.H. Whittles. 1993. The influence of sampling method on the classification of wetland macroinvertebrate communities. Hydrobiologia. 257: 4756.

Clarkson B.R., Ausseil A.E., Gerbeaux P. 2013. Wetland ecosystem services. In Dymond Jr. ed. Ecosystem services in New Zealand - conditions and trends. Manaaki Whenua Press, Lincoln, New Zealand.

Coleman, J., K. Hench, K. Garbutt, A. Sexstone, G. Bissonnette, J. Skousen. 2000. Treatment of domestic wastewater by three plant species in constructed wetlands. Water, Air and Soil Pollution. 128: 283-295.

Confer, S.R., and W.A. Niering. 1992. Comparison of created and natural freshwater emergent wetlands in Connecticut (USA). Wetlands Ecology and Management. 2(3):143-156.

Cowardin, L.M., V. Carter, F.C. Golet, E. T. LaRoe. 1979. Classification of wetlands and deepwater habitats of the United States. United States Fish and Wildlife Service, Washington D.C. USA.

Daubenmire, R.F. 1959. Canopy coverage method of vegetation analysis. Northwest Science 33:43-64.

Dahl, T.E. 2011. Status and trends of wetlands in the conterminous United States 2004 to 2009. U.S. Department of the Interior, Fish and Wildlife Service, Washington D.C.

Davis, C.A., and J.R. Bidwell. 2008. Response of aquatic invertebrates to vegetation management and agriculture. Wetlands. 28(3):793-805.

De Steven, D., and Gramling, J.M. 2012. Diverse characteristics of wetlands restored under the Wetlands Reserve Program in the Southeastern United States. Wetlands. 32:593-604. 
De Steven, D., and J.M. Gramling. 2013. Multiple factors influence the vegetation composition of Southeast U.S. wetlands restored in the Wetlands Reserve Program. The Journal of the Torrey Botanical Society. 140: (4): 453-464.

English, M.D., G.J. Robertson, L.E. Peck, M.L. Mallory. 2017. Agricultural food resources and the foraging ecologies of American black ducks (Anas rubripes) and mallards (Anas platyrhynchos) at the northern limits of their winter ranges. Urban Ecosystems. 20(6): 13111318.

Entrekin, S.A., E.J. Rosi-marshall, J.L. Tank, T.J. Hoellein, G.A. Lamberti. 2007. Macroinvertebrate secondary production in 3 forested streams of the upper Midwest, USA. Journal of the North American Benthological Society. 26(3): 472-490.

Euliss, N.H. and S.W. Harris. 1987. Feeding ecology of northern pintails and green-winged teal wintering in California. Journal of Wildlife Management. 51: 724-732.

Evans-Peters, G.R., B.D. Dugger, M.J. Petrie. 2012. Plant community composition and waterfowl food production on Wetland Reserve Program easements compared to those on managed public lands in Western Oregon and Washington. Wetlands. 32: 391-399.

Fennessy, S., and C. Craft. 2011. Agricultural conservation practices increase wetland ecosystem services in the Glaciated Interior Plains. Ecological Applications. 21(3): 49-64.

Fleming, K.S., R.M. Kaminski, M.L. Schummer, N.D. Nelms, G.N. Ervin, T.E. Tietjen. 2015. Species richness and density of wintering ducks on Wetlands Reserve Program easements in Mississippi. Wildlife Society Bulletin. 39(2): 310-318.

Galatowitsch, S.M., and A.G. van der Valk. 1996. Characteristics of recently restored wetlands in the prairie pothole region. Wetlands. 16(1): 75-83. 
Gingerich, R.T., and J.T. Anderson. 2011. Litter decomposition in created and reference wetlands in West Virginia, USA. Wetlands Ecology and Management. 19:449-458.

Glass, G.V., P.D. Peckham, J.R. Sanders. 1972. Consequences of failure to meet assumptions underlying fixed effects analyses of variance and covariance. Review of Educational Research. 42(3): $237-288$

Gleason, J.E., and R.C. Rooney. 2017. Aquatic macroinvertebrates are poor indicators of agricultural activity in northern prairie pothole wetlands. Ecological Indicators. 81: 333-339.

Gleason, R.A., N.H. Euliss Jr., B.A. Tangen, M.K. Laubhan, B.A. Browne. 2011. USDA conservation program and practice effects on wetland ecosystem services in the Prairie Pothole Region. Ecological Applications. 21(3): 65-81.

Gleason, R.A., and B.A. Tangen. 2008a. Floodwater storage. In R.A. Gleason, M.K. Laubhan, N.H. Euliss Jr., editors. Ecosystem services derived from wetland conservation practices in the United States Prairie Pothole Region with an emphasis on the U.S. Department of Agriculture Conservation Reserve and Wetlands Reserve Programs. Professional paper 1745. U.S. Geological Survey, Reston, Virginia, USA.

Gleason, R.A., and B.A. Tangen. 2008b. Reduction of sedimentation and nutrient loading. In R.A. Gleason, M.K. Laubhan, N.H. Euliss Jr., editors. Ecosystem services derived from wetland conservation practices in the United States Prairie Pothole Region with an emphasis on the U.S. Department of Agriculture Conservation Reserve and Wetlands Reserve Programs. Professional paper 1745. U.S. Geological Survey, Reston, Virginia, USA. 
Hall, D.L., M.R. Willig, D.L Moorhead, R.W. Sites, E. B. Fish, T.R. Mollhagen. 2004. Aquatic macroinvertebrate diversity of playa wetlands: the role of landscape and island biogeographic characteristics. Wetlands. 24(1): 77-91.

Hansson, L.A., C. Bronmark, P. Anders Nilsson, K. Abjornsson. 2005. Conflicting demands on wetland ecosystem services: nutrient retention, biodiversity, or both? Freshwater Biology. 50: 705-714.

Jorde, D.G., G.L. Krapu, R.D. Crawford, M.A. Hay. 1984. Effects of weather on habitat selection and behavior of mallards wintering in Nebraska. Condor 86: 258-265.

Kaminski, M.R., G.A. Baldassarre, A.T. Pearse. 2006. Waterbird responses to hydrological management of Wetlands Reserve Program habitats in New York. Wildlife Society Bulletin. 34(4): 921-926.

Kellogg, L. 1994. Second edition. Save our streams monitor's guide to aquatic macroinvertebrates. Izaak Walton League of America.

Laubhan, M.K., and R.A. Gleason. 2008. Plant community quality and richness. In R.A.

Gleason, M.K. Laubhan, N.H. Euliss Jr., editors. Ecosystem services derived from wetland conservation practices in the United States Prairie Pothole Region with an emphasis on the U.S. Department of Agriculture Conservation Reserve and Wetlands Reserve Programs. Professional paper 1745. U.S. Geological Survey, Reston, Virginia, USA.

Lenth, R., J. Love, M. Herve. 2018. Estimated marginal means, aka least-squares means. R version 1.1.3. 
Long, A.L., K.M Kettenring, C.P. Hawkins, C.M. U. Neale. Distribution and drivers of a widespread invasive wetland grass, Phragmites australis in wetlands of the Great Salt Lake, Utah, USA. Wetlands. 37(1) 45-57.

Lopez-Pomares, A., G.M. Lopez-Iborra, C. Martin-Cantarino. 2015. Irrigation canals in a semiarid agricultural landscape surrounded by wetlands: their role as a habitat for birds during the breeding season. Journal of Arid Environments. 118: 28-36.

Lupien, N.G., G. Gauthier, C. Lavoie. 2015. Effect of the invasive common reed on the abundance, richness, and diversity of birds in freshwater marshes. Animal Conservation. 18(1): $32-43$.

McDonald, J.H. 2014. Handbook of biological statistics. $3^{\text {rd }}$ Edition. Sparky House Publishing Baltimore, Maryland, USA. Pp 133-136.

Mitsch, W.J., and M.E. Hernandez. 2013. Landscape and climate change threats to wetlands of North and Central America. Aquatic Sciences. 75:133-149.

Morin, R.S., G.M. Domke, B.F. Walters. 2017. Forests of West Virginia, 2016. Resource Update FS-123. United States Department of Agriculture, Forest Service. Newtown Square, PA, USA. Morrissey, C.A., P. Mineau, J.H. Devries, F. Sanchez-Bayo, M. Liess, M.C. Cavallaro, K. Liber. 2015. Neonicotinoid contamination of global surface waters and associated risk to aquatic invertebrates: a review. Environment International. 74: 291-303.

Nelms, K.D. editor. 2007. Wetland management for waterfowl handbook. Natural Resources Conservation Service, Mississippi River Trust.

Nelson, J.W., J.A. Kadlec, H.R. Murkin. 1990. Responses by macroinvertebrates to cattail litter quality and timing of litter submergence in a northern prairie marsh. Wetlands. 10(1): 47-60. 
Oksanen, J., F. G. Blanchet, M. Friendly, R. Kindt, P. Legendre, D. McGlinn, P. R. Minchin, R. B. O'Hara, G. L. Simpson, P. Solymos, M. Henry, H. Stevens, E.Szoecs, H Wagner (2018). vegan: Community Ecology Package. R package version 2.4-6. https://CRAN.Rproject.org/package=vegan

Olmstead, V.G., E.B. Webb, R.W. Johnson. 2013. Moist-soil seed biomass and species richness on Wetland Reserve Program Easements in the Mississippi Alluvial Valley. Wetlands. 33: 197206.

O’Neal. B.J., E.J. Heske, J.D. Strafford. 2008. Waterbird response to wetlands restored through the Conservation Reserve Enhancement Program. The Journal of Wildlife Management. 72(3): 654-664.

Osborn, J.M., H.M. Hagy, M.D. McClanahan, J.B. Davis, M.J. Gray. 2017. Habitat selection and activities of dabbling ducks during non-breeding periods. Journal of Wildlife Management. 81(8): 1482-1493.

Peralta, A.L., M.E. Muscarella, J.W. Matthews. 2017. Wetland management strategies lead to tradeoffs in ecological structure and function. Elementa Science of the Anthropocene. 5(74):1-13 R Core Team (2016). R: A language and environment for statistical computing. R Foundation for Statistical Computing, Vienna, Austria.

Rico, A. and P.J. Van Den Brink. 2015. Evaluating aquatic invertebrate vulnerability to insecticides based on intrinsic sensitivity, biological traits, and toxic mode of action. Environmental Toxicology and Chemistry. 34(8): 1907-1917.

Rojas, I.M., and J.B. Zedler. 2015. An invasive exotic grass reduced sedge meadow species richness by half. Wetlands Ecology and Management. 23(4): 649-663. 
Scatolini, S.R., and J.B. Zedler. 1996. Epibenthic invertebrates of natural and constructed marshes of San Diego Bay. Wetlands. 16(1):24-37.

Shannon, C.E. and W. Weaver. 1949. The Mathematical Theory of Communication. University of Illinois Press, Urbana.

Smith, A.M., C. R. Adams, C. Wiese, S.B. Wilson. 2016. Re-vegetation with native species does not control the invasive Ruellia simplex in a floodplain forest in Florida, USA. Applied Vegetation Science. 19: 20-30.

Stapanian M.A., B. Gara, W. Schumacher. 2018. Surrounding land cover types as predictors of palustrine wetland vegetation quality in conterminous USA. Science of the Total Environment. 619: $366-375$.

Stanczak, M., and J.B. Keiper. 2004. Benthic invertebrates in adjacent created and natural wetlands in northeastern Ohio, USA. Wetlands. 24(1): 212-218.

Strain, G.F., P.J. Turk, J.T. Anderson. 2014. Functional equivalency of created and natural wetlands: diet composition of red-spotted newts (Notophthalmus viridescens viridescens). Wetlands Ecology and Management. 22: 659-669.

Strain, G.F., P.J. Turk, A.N. Tri, J.T. Anderson. 2016. Anuran occupancy of created wetlands in the Central Appalachians. Wetlands Ecology and Management. 25:369-384.

De Szalay, F.C. and V.H. Resh. 2000. Factors influencing macroinvertebrate colonization of seasonal wetlands: responses to emergent plant cover. Freshwater Biology. 45: 295-308.

Tapp, J.L., and E.B. Webb. 2015. Aquatic invertebrate food base for waterbirds at the Wetland Reserve Program easements in the Lower Mississippi Alluvial Valley. Wetlands. 35:183-192. 
Tavernia, B.G., and J.M. Reed. 2012. The impact of exotic purple loosestrife (Lythrum salicaria) on wetland bird abundances. The American Midland Naturalist. 168(2): 352-363.

Tiner, R.W., I. Kenenski, T. Nuerminger, J. Eaton, D.B. Foulis, G.S. Smith, W.E. Frayer. 1994. Recent wetland status and trends in the Chesapeake watershed (1982-1989). U.S. Fish and Wildlife Service Ecological Services Technical Report. Annapolis, Maryland, USA.

U.S. Department of Agriculture. 2016. NRCS Conservation Programs: Agricultural Conservation Easement Program (ACEP). Financial Management Modernization Initiative (FMMI) November 2016. Natural Ressources Conservation Service, Washington, D.C., USA. Accessed 24 April 2018. <http://www.nrcs.usda.gov/Internet/NRCS_RCA/reports/srpt_cp_acep.html>

U. S. Fish and Wildlife Service. 2016. National Wetlands Inventory website. U.S. Department of the Interior, Fish and Wildlife Service, Washington, D.C. <http://www.fws.gov/wetlands/>

Veselka, W. and J.T. Anderson. 2011. The West Virginia Wetland Rapid Assessment Procedure. Second edition. West Virginia University Environmental Research Center, Morgantown, West Virginia.

West Virginia Department of Environmental Protection. 2018. West Virginia save our streams field guide to aquatic invertebrates. Fayetteville, West Virginia, USA.

West Virginia Geological and Economic Survey. 2017. Physiographic provinces of West Virginia. <http://www.wvgs.wvnet.edu/www/geology/geolphyp.htm>. Accessed 6 April 2018. Zedler, J.B., and S. Kercher. 2005. Wetland resources: Status, trends, ecosystem services, and restorability. Annual Review of Environment and Resources. 30:39-74. 


\title{
Chapter 2: Influence of Agricultural Conservation Easement Program Wetland Practices on Winter Occupancy of Passerellidae Sparrows
}

\begin{abstract}
Wetlands enrolled in the Agricultural Conservation Easement Program (ACEP) in West Virginia have never been widely evaluated to determine how they function as wildlife habitat in comparison to other available wetland habitat in the state. Wetlands enrolled in ACEP have several characteristics such as their location on private, agricultural land and passive management that make them a potential source of unique wetland habitat. We measured the wintering occupancy of sparrows in the family Passerellidae and apparent avian species richness on ACEP wetlands and a set of reference wetlands located on public land in West Virginia to determine if ACEP wetlands are used similarly by avian species in the winter to other available wetland habitat. Occupancy probability of dark-eyed juncos (Junco hyemalis) and swamp sparrows (Melospiza georgiana) was higher on ACEP sites than reference sites (swamp sparrow ACEP occupancy probability: 43\%, reference occupancy probability: 19\%) (dark-eyed junco ACEP occupancy probability: 23\%, reference occupancy probability: 4\%). Apparent species richness, song sparrow occupancy, and white-throated sparrow occupancy were predicted best by characteristics other than wetland type (ACEP or reference) such as wetland size and vegetative associations. Our results indicate that ACEP wetlands are providing winter wetland avian habitat as well as or better than other available wetlands. Because of this, maintenance and expansion of ACEP in West Virginia would continue to provide valuable wetlands in areas that are otherwise lacking these habitats.
\end{abstract}




\section{Introduction}

Wetlands act as wildlife habitat throughout all seasons for a myriad of species (Dahl 2011). While wetland habitat is frequently linked to waterfowl, wetlands also provide habitat for diverse avian species, including many passerine birds. The vegetation associated with emergent, scrub-shrub, and forested wetlands (Cowardin et al. 1979) provide resources for passerine species throughout the year. Emergent sedges and other grasses present on freshwater-emergent wetlands provides nesting habitat and screening cover from predation (Murkin et al. 1997, Riffell et al. 2001). The vegetative structural diversity present on scrub-shrub or forested wetlands also influences passerine wetland use and promotes species richness by providing differing vegetation heights and types that align with a broad range of species' nesting and roosting habitat requirements (Moreno-Mateos et al. 2009). A small number of snags and deciduous trees can contribute to the vertical and horizontal vegetative diversity of a wetland that may also influence overall species richness by creating diverse habitat conditions that fulfill different species' habitat requirements (Riffell et al. 2001).

Specifically in the winter, the wetland vegetation present on sites provides foraging habitat, thermal cover, and protection from predation in the form of dense shrubs, herbaceous material, and emergent vegetation (Beck and Watts 1997, Carr and Lima 2014). Passerine species foraging in the winter selected foraging sites under shrub cover as opposed to foraging in the open and gaining thermal benefits from direct sunlight (Carr and Lima 2014). New world sparrows in the family Passerellidae that overwinter on wetlands have general habitat associations that reflect these vegetative characteristics. Sparrow species were more abundant in the winter on agricultural fields with areas of thick screening vegetation (Marcus et al. 2000, Plush et al. 2013). Species such as song sparrows (Melospiza melodia) and white-throated 
sparrows (Zonotrichia albicollis) selected winter foraging plots with dense screening cover or foraged in areas closer to screening cover to reduce the risk of predation (Beck and Watts 1997, Schneider 1984). Winter site selection of Passerellidae sparrows may be impacted by broader landscape-scale factors in addition to site-level vegetative characteristics. Wetland size is a predictor for swamp sparrow occupancy and abundance of a number of Passerellidae species (Smith and Chow-Fraser 2010, Riffell et al. 2001). Larger wetlands can have a higher diversity of plants or larger bodies of water that are conducive to a greater number of species and individuals. Similarly, wetlands that occur within complexes of different habitat types could contribute to the species that occupy the wetland sites. Breeding season studies assessing the impact of habitat heterogeneity found that different habitat types near wetland sites increased species richness (Lorenzon et al. 2016), and this concept can also be applied to winter habitat use due to differing species-specific habitat associations.

While wetlands act as important wintering habitat for avian species, over $50 \%$ of wetlands in North America have been lost to drainage and development (Dahl 2011). Remaining wetlands are often exposed to agricultural runoff and physical impacts from livestock grazing (Mitsch and Hernandez 2013) and continue to be lost to urban and residential development (Dahl 2011). Due to the important ecological functions and services provided by wetlands, their rapid loss has led to conservation programs and policies aimed at reversing past losses. The Agricultural Conservation Easement Program (ACEP; formerly the Wetland Reserve Program) is a platform administered through the Natural Resources Conservation Service (NRCS) that provides financial and technical assistance to landowners in restoring wetlands on their property by establishing wetland vegetation and hydrology. The objectives of ACEP wetland easements are to provide wetland ecosystem services in agricultural areas while maximizing wildlife habitat 
(Personal communication, M. Oliver, USDA). Once the wetland is enrolled in ACEP, the landowner retains title ownership and may dictate who has access to the wetland. The ultimate goal of restoring wetlands on private lands is for the land to return to its natural hydrologic state, therefore restorations are typically designed to not require active management (Personal communication, M. Oliver, USDA). Since its inception in 1996, over 500,000 ha of wetlands have been restored or created through this program (Kaminski et al. 2006). Between 1996 and 2011, 24 conservation easements were enrolled in the WRP and ACEP in West Virginia totaling approximately 179 ha of wetlands.

With any conservation program or policy, it is important to monitor the associated management practices to determine if program objectives are being met. However wetlands enrolled in ACEP have not been evaluated in West Virginia. The wetlands enrolled in ACEP are located on private land with the exception of one site located on a wildlife management area and are passively managed. Past studies of wetlands in West Virginia have focused on a comparison between one ACEP and one reference wetland, or mitigated wetlands (Balcombe et al. 2005a, 2005b, 2005c, Clipp et al. 2017, Strain et al. 2014). Generally, studies comparing wetlands occur on unmanaged and managed wetlands (Anderson and Smith 1998, Anderson and Smith 2000, Fleming et al. 2015, Kaminski et al. 2006, O’Neal et al. 2008). By comparing avian use of private ACEP wetlands to public wetlands we are studying an overlooked source of wetland habitat. Additionally, many wetland-based studies occur in the summer, which has created a research gap in winter-wetland information (Clipp et al. 2017). A study comparing ACEP wetlands located in West Virginia to wetlands located on public land provides a means of assessing ACEP wetland wildlife habitat against another important source of wetland wildlife habitat. 
By evaluating winter sparrow use of ACEP wetlands we are gaining a comprehensive perspective of an often neglected component of wetland management. We evaluated the ability of ACEP conservation easements to provide wildlife habitat by comparing: (1) avian species richness, and (2) occupancy probability of wintering Passerellidae species on ACEP wetlands and reference wetlands on public land while controlling for vegetative characteristics which could influence occupancy. We hypothesized that occupancy probability of Passerellidae sparrows and avian species richness on ACEP wetlands would be equal to or higher relative to reference wetlands, due to the agricultural matrix surrounding ACEP wetlands. We hypothesized that occupancy overall would be positively correlated with the size of the wetland and dense screening cover in the form of herbaceous and shrubby material.

\section{Study Area}

We conducted wintering avian surveys on ACEP and reference wetlands in West Virginia in the winters of 2016 - 2017 and 2017-2018. This study occurred on 20 ACEP and 13 reference wetlands located in 17 counties in West Virginia (Figure 1). Wetland habitat in West Virginia is scarce: approximately $80 \%$ of West Virginia is forested (Morin et al. 2017), while $<1 \%$ of the state's surface is covered by wetlands (Tiner et al. 1994). Because of this, many wetland dependent avian species are not common in West Virginia. West Virginia is composed of several physiographic provinces. The wetland sites included in this study were located within the Appalachian Plateau, Allegheny Mountain Section, Valley and Ridge, and the Great Valley physiographic provinces (West Virginia Geological and Economic Survey. 2017). Generally, the climate in West Virginia is humid continental, meaning that winters tend to be cold, averaging around $-6^{\circ} \mathrm{C}$ (Runkle et al. 2017).

We included all West Virginia wetlands enrolled in ACEP with the exception of four 
sites where we were denied access by the landowners. The reference wetlands were located on public land in wildlife management areas, state parks, national forests, or property owned by The Nature Conservancy. Wetlands ranged in size from $<0.4$ ha to 32 ha. All sites were either freshwater palustrine emergent, forested, or scrub-shrub wetlands (Cowardin et al. 1979). Emergent wetlands were dominated by rooted hydrophytic vegetation such as cattails (Typha spp.), bulrush (Scirpus spp.), and sedges (Carex spp.). Forested wetlands had an over-story of trees and were dominated by woody vegetation $>6 \mathrm{~m}$ tall. Scrub-shrub wetlands were dominated by woody vegetation $<6 \mathrm{~m}$ tall such as alders (Alnus spp.) and buttonbush (Cephalanthus occidentalis) (Cowardin et al. 1979). The ACEP wetland sites were located on private land within an agricultural landscape composed of hay, corn, or pasture. ACEP wetlands that were located on actively used livestock pasture had fencing to exclude livestock.

\section{Methods}

\section{Reference Site Selection}

We selected reference sites from publicly accessible wetlands in proximity to ACEP wetlands. We used the National Wetlands Inventory data layer (US Fish and Wildlife Service 2016) in ArcMap 10.4 (ESRI 2016) to identify wetlands in West Virginia wildlife management areas, state parks and state forests, or property owned by The Nature Conservancy. We then limited this list to include only wetlands that were $\leq 32$ ha; classified as emergent, scrub-shrub, or forested; and in the same or an adjacent county as ACEP wetlands. There were fewer reference sites than ACEP sites that fit all of these criteria, so we included all potential reference sites in the study.

\section{Point Counts}

To determine species richness and Passerellidae occupancy, we conducted point counts 
throughout each of the sites. We established point count locations in two different ways depending on the characteristics of the wetland site. For sites that had clear distinctions between wetland and upland habitats (i.e., included standing water), we first drew a transect $50 \mathrm{~m}$ from the wetland edge using the world imagery satellite basemap at $1 \mathrm{~m}$ (ESRI 2016). For wetlands with no standing water (e.g., small streams or saturated soils), we placed a transect through the centroid of wetland sites running lengthwise across the site (Figure 2). We then placed point counts along these transects or around obstacles such as standing water. We selected the location of the first point count along each transect with a uniform random number generator, with every point along the transect equally likely to be selected. Because our sites varied in size, we placed point counts $150 \mathrm{~m}$ apart along the rest of the transect to allow for at least one point count per site.

We obtained detection and non-detection data from unlimited radius, single observer, 10minute point counts. We used visual and auditory detection to determine species presence and recorded the approximate distance to the individual bird using distance categories of $<50 \mathrm{~m}$, 50-100 m, and >100 m (Ralph et al. 1993). If we were able to continue to visually detect the same individual bird and detected it on more than one point count, we made note of if the bird was already recorded on a previous point count to avoid double counting bird observations. Each wetland site was visited twice each year by the same observer each time between November and February 2016-2017 and 2017-2018.

\section{Detection probability covariates}

During point counts, we recorded several variables thought to influence detectability. We classified sky condition as clear skies, partly cloudy, overcast, light precipitation, and heavy precipitation. Point counts were not conducted in sky conditions categorized as heavy 
precipitation. We measured noise disturbance level with a sound level meter that recorded noise to the nearest 0.5 decibel. We measured wind speed in meters per second with a Kestrel 1000 hand-held anemometer, and we recorded temperature in degrees Celsius. We also recorded time of day and day of year that the point counts were conducted (Table 1).

\section{Occupancy Covariates}

We measured vegetative characteristics thought to influence the probability of sparrow occupancy at each of the wetland sites during the first round of point count surveys once each year. We measured horizontal vegetative cover at each point count location using a nested quadrat design (Mueller-Dombois and Ellenburg 1974) (Figure 3). With the point count at the center, we placed five $1 \mathrm{x} 1 \mathrm{~m}$ quadrats every $5 \mathrm{~m}$ along the transect line to measure horizontal vegetative cover. Within the $1 \mathrm{x} 1 \mathrm{~m}$ quadrats, we measured vegetative cover using Daubenmire cover classes (Daubenmire 1959). We recorded Daubenmire cover class of herbaceous, scrubshrub, bare ground, open water, and woody vegetation. The herbaceous category included all forbs and grass species such as goldenrod (Solidago spp.), sedge species (Cyperaceae), bulrush (Scirpus spp.), cattails (Typha spp.), and common reed (Phragmites australis). The scrub-shrub category was defined as non-herbaceous vegetation that was not a tree $(<6$ meters tall). Included in this category was multiflora rose (Rosa multiflora), greenbriar (Smilax spp.) and button bush (Cephalanthus occidentalis). Bare ground was defined as areas that did not have any vegetation including roadways, railroad tracks, unvegetated mud flats and cleared trails. Sampling points that were in water deep enough to obscure any vegetation were recorded as water points and no vegetation measurements were taken. The woody vegetation category included any woody vegetation such as trees, snags, and logs. Additionally, we placed two $5 \times 5$ m quadrats five m from the center to measure percent shrub cover, which we also assessed using Daubenmire cover 
classes (Daubenmire 1959).

Because avian detections were sparse or non-existent in some cover-class categories, we collapsed the six Daubenmire classes into two or three larger categories to ensure detections occurred in all vegetative categories (Table 1). We also tested for co-linearity between each variable, and omitted variables with a correlated $\mathrm{r}$ value $>0.5$ (Kendall 1938).

\section{Statistical Analyses}

Single-Species Occupancy Modeling

We estimated the probability each point count was occupied by four Passerellidae species: song sparrows (Melospiza melodia), swamp sparrows (Melospiza georgiana), dark-eyed juncos (Junco hyemalis), and white-throated sparrows (Zonotrichia albicollis) with single-season occupancy models (MacKenzie et al. 2002). We modeled the occupancy probability of these species because they had the highest number of individual detections within the family Passerellidae on surveys. All other Passerellidae species we detected had a total number of individuals $<30$, therefore these four species had the most adequate sample sizes for modeling occupancy. We used replicate surveys to model the probability of detection of a species conditional on that species' occupancy of a site (MacKenzie et al. 2002).

We fit four models for each species using unmarked version 3.3.3 (Fiske and Chandler 2011) with program $\mathrm{R}$ version 3.3.1 ( $\mathrm{R}$ Core Team 2016). The first was a detection-only model that included all of the detection covariates and assumed constant occupancy probability (Table 1). In an attempt to create a more parsimonious detection model, we removed any detection covariates with an absolute value of the ratio of point estimate to standard error (i.e., a Wald test statistic) $<1.64$, indicating a p-value $>0.1$, and fit a second detection-only model. We retained the variables from the detection model with the lowest AIC when next modeling occupancy as a 
function of environmental variables. The $3^{\text {rd }}$ model we fit for each species included the detection variables from the previous step with the lowest AIC and assumed occupancy probability was a function of all environmental variables (Table 1). As before, we sought a parsimonious model by fitting a $4^{\text {th }}$ model that omitted occupancy covariates with an absolute value of the ratio of point estimate to standard error $<1.64$. We believe this approach to model selection is justified because we developed an a priori list of environmental variables we hypothesized would influence sparrow occupancy, which we measured in the field. Once we developed this list of environmental variables, we had no further biological justification for including some combinations of variables but not others. We thus modeled all variables which were hypothesized to have an effect on sparrow occupancy, and pared this variable set down by removing variables with low point estimate to standard error ratios.

\section{Species Richness}

We measured apparent avian species richness as the total number of species detected at each wetland site (i.e., we treated the wetland, not the point count, as the unit of replication) using the glm function in program $\mathrm{R}$ version 3.3.3 (R Core Team 2016). We assumed species richness at each wetland was a Poisson random variable, which we modeled as a function of ACEP or reference wetland type, wetland size, and year. We evaluated apparent species richness at the wetland as opposed to the point count unit of replication because we were interested in modeling richness as a function of the broad wetland site-level variables of wetland type, size, and year. These variables apply to the wetland site overall and do not need to be broken down to the point-count level. 


\section{Results}

We surveyed 197 total point counts on 20 ACEP and 13 reference sites over both survey years, with 118 point counts on $\mathrm{ACEP} \operatorname{sites}(\overline{\mathrm{x}}=4, \mathrm{se}=0.51, \min =1, \max =9)$ and 79 point counts on reference $\operatorname{sites}(\overline{\mathrm{x}}=4, \mathrm{se}=0.50, \min =1, \max =7)$. Over the two survey winters, 61 avian species overall and 10 Passerellidae sparrow species were detected. Over both survey years and between ACEP and reference sites, song sparrows were the most abundant ( $n=547$ detections), followed by white-throated sparrows $(n=166)$, dark-eyed juncos $(n=134)$, and swamp sparrows $(n=68)$. All Passerellidae species were detected on both ACEP and reference sites except for American tree sparrow (Spizella arborea), fox sparrow (Passerella iliaca), Savannah sparrow (Passerculus sandwichensis), and white-crowned sparrow (Zonotrichia leucophrys), which were detected only at ACEP sites (Table 2). Since there was little model selection uncertainty (e.g., AIC weight of top models all $>0.80$, Table 3), we report results only from models with the lowest AIC score.

After controlling for vegetative characteristics, we found swamp sparrows and dark-eyed juncos were more likely to occur on ACEP wetlands relative to reference wetlands (Figure 4). The occupancy probabilities for song sparrows and white-throated sparrows were not significantly different between ACEP and reference sites. Swamp sparrow detection probability was positively associated with noise disturbance (Figure 5). Swamp sparrow occupancy was positively associated with the ACEP wetland type, wetland size and was greater in the winter of 2016 - 2017 (Figure 6). Dark-eyed junco detection probability was positively associated with sky condition and negatively associated with temperature and wind speed (Figure 7). Dark-eyed junco occupancy was negatively associated with wetland size and was positively associated with the ACEP wetland type and the presence of shrubs at the $5 \times 5 \mathrm{~m}$ scale (Figure 8). Song sparrow 
detection probability was negatively correlated with wind speed, time of day, and day of year, and positively associated with noise disturbance (Figure 9). Song sparrow occupancy was greater at sites with $<50 \%$ bare ground cover (Figure 10). White-throated sparrow detection probability was negatively associated with sky condition (Figure 11). White-throated sparrow occupancy was not associated with any of the occupancy covariates we modeled, and the top occupancy model for this species was the intercept-only model.

Apparent species richness was positively associated with wetland size (Figure 12). We found no statistical difference in richness between years or at ACEP vs. reference sites. Of the 61 total species we detected, 13 species were detected only at the ACEP wetland sites including American tree sparrow, cedar waxwing (Bombycilla cedrorum), Cooper's hawk (Accipiter cooperii), fox sparrow, green-winged teal (Anas carolinensis), house sparrow (Passer domesticus), yellow-rumped warbler (Setophaga coronata), osprey (Pandion haliaetus), rubycrowned kinglet (Regulus calendula), Savannah sparrow, white-crowned sparrow, Wilson's snipe (Gallinago delicata), and yellow-bellied sapsucker (Sphyrapicus varius) (Table 4). Three species: winter wren (Troglodytes hiemalis), black vulture (Coragyps atratus), and mourning dove (Zenaida macroura) were only detected on reference sites (Table 4).

\section{Discussion}

We found that ACEP wetlands function as winter habitat for a variety of avian species at least as well as reference wetlands on public lands. Positive associations with the ACEP over the reference wetlands of two Passerellidae species may be a consequence of ACEP wetlands predominantly occurring on agricultural land. This created a matrix of different habitats that appeals to a diversity of species including open fields, forested edges, shrub buffers, and wetlands. Habitat heterogeneity has been positively associated with avian diversity, richness, and 
abundance in studies globally (Lee and Martin 2017, Siriwardena et al. 2012). Dark-eyed juncos were more likely to be found on ACEP wetlands over reference wetlands. Dark-eyed juncos forage on the ground with small amounts of shrub or tree cover (Elphick et al. 2001), which occurred more on ACEP wetlands. ACEP sites were better able to provide this type of habitat because of the pasture immediately surrounding some of these sites. Reference wetlands were typically located within a contiguous forested or wetland landscape which may have excluded some wintering Passerellidae species that require a certain amount of open-field habitat, edge, or habitat diversity. Similarly, swamp sparrows were more likely to be found on ACEP wetlands and are often associated with native emergent vegetation (Harms and Dinsmore 2015). While emergent vegetation was prevalent on both ACEP and reference sites, invasive herbaceous material was higher on reference sites (Lewis, Chapter 1). Our findings suggest that ACEP wetlands contribute wetland habitat to promote heterogeneity within agricultural fields that would otherwise lack this type of habitat. ACEP provides a unique mechanism for restoring wetlands on private agricultural lands that previously did not have wetlands on them. This heterogeneity afforded by the wetland areas serves as an important source of avian habitat.

It is also possible that the winter selection of these sites we observed may not rely on the fact that the site was a wetland, but rather that they were productive areas of dense vegetation within areas these species were already overwintering in. With the exception of swamp sparrows, the other focal species tend to have general wintering habitat requirements that are not exclusive to wetlands. However, swamp sparrows are typically associated with wetland habitat (Harms and Dinsmore 2015) and their greater occupancy on ACEP sites over reference sites is an indication that these sites are acting specifically as wetland habitat, not just general habitat patches of dense vegetation within the landscape. 
Consistent with other studies, we found evidence that screening cover is an important component of wintering avian habitat. Even small areas of herbaceous buffers can promote avian presence through all seasons (Baldwin et al. 2007, Blank et al. 2011, Harms and Dinsmore 2015, Marcus et al. 2000). Dense herbaceous or shrubby cover provides hiding and foraging habitat, and also acts as thermal cover in the winter (Carr and Lima 2014). Sparrow species select wintering habitat with screening cover (Beck and Watts 1997), and select feeding sites near cover in the form of shrubs (Schneider 1984). Song sparrows were more likely to occur at sites with less bare ground and dark-eyed juncos were more likely to occur at sites with at least some shrubs at the $5 \times 5 \mathrm{~m}$ scale which could be an indication that Passerellidae sparrows select wintering habitat with denser herbaceous and shrub screening cover. The absence of any significant association between swamp sparrow occupancy and dense vegetation is contrary to what has been found previously (Harms and Dinsmore 2015). This may be because swamp sparrows select habitat with dense vegetation at a different scale than what we measured, or select wintering habitat based on other habitat-scale characteristics.

We also found that wetland size was a significant predictor of dark-eyed junco and swamp sparrow occupancy, and apparent species richness. This finding is consistent with the theory of island biogeography that postulates that species richness increases with island size (MacArthur and Wilson 1967). Because many of the sites enrolled in ACEP were isolated wetland areas within an agricultural matrix, these habitats could have acted as wetland "islands". Larger wetlands had more available habitat and thus could have appealed to a wider array of species. Wintering sparrows specifically partition habitat space to optimize foraging and protection from predation by foraging in flocks or close to cover (Pulliam and Mills 1977). Therefore, larger wetland areas could provide more foraging space for flocks as well as more 
vegetative cover. Swamp sparrow occupancy has been positively associated with wetland size in past studies (Riffell et al. 2001). This association between swamp sparrows and wetland size may also explain our observation of swamp sparrow detection being positively impacted by noise disturbance: our largest wetland site that had the highest number of swamp sparrows was also the noisiest as it was located between highways with traffic noise.

Larger wetlands can provide larger areas of suitable winter habitat, or have a diversity of resources that appeal to a greater number of species. While larger wetlands may increase species richness and occupancy probability for some species, small wetland areas can provide equally suitable habitat (Pasinelli et al. 2008). A small amount of wetland habitat combined with other habitat types such as forested areas and open fields could fulfill multiple foraging, thermal cover, and shelter habitat requirements in the winter. The negative association we found between darkeyed juncos and wetland size could indicate that dark-eyed juncos selected winter habitat in areas that are made up of combinations of small habitat types. Species such as dark-eyed juncos that are not interior habitat specialists may have higher densities in areas with increased edge habitat (Ambuel and Temple 1983). Their presence on smaller wetland sites could also be attributed to vegetative or site characteristics that occupied a different scale than the variables we measured.

West Virginia is a state not often associated with wetland ecosystems. Less than $1 \%$ of West Virginia's surface is covered by wetlands. However, these wetlands provide crucial ecosystem services and contribute significantly to the state's wildlife habitat (Fretwell et al. 1996). Most of the reference wetlands included in our study occurred within a forested matrix (Lewis, Chapter 1). ACEP establishes wetlands within an agricultural matrix on private land, which provides early successional wetland habitat that is an important component of wintering sparrow habitat. 
ACEP wetlands had similar overall avian richness as the reference wetlands. This indicates that the wildlife habitat creation objective of ACEP is being met in terms of wintering avian use. Additionally, occupancy of some sparrow species was the same or higher than reference wetlands. A continuation and expansion of ACEP in West Virginia is important for both wetland and wildlife habitat creation in a state with a small amount of wetland resources. 


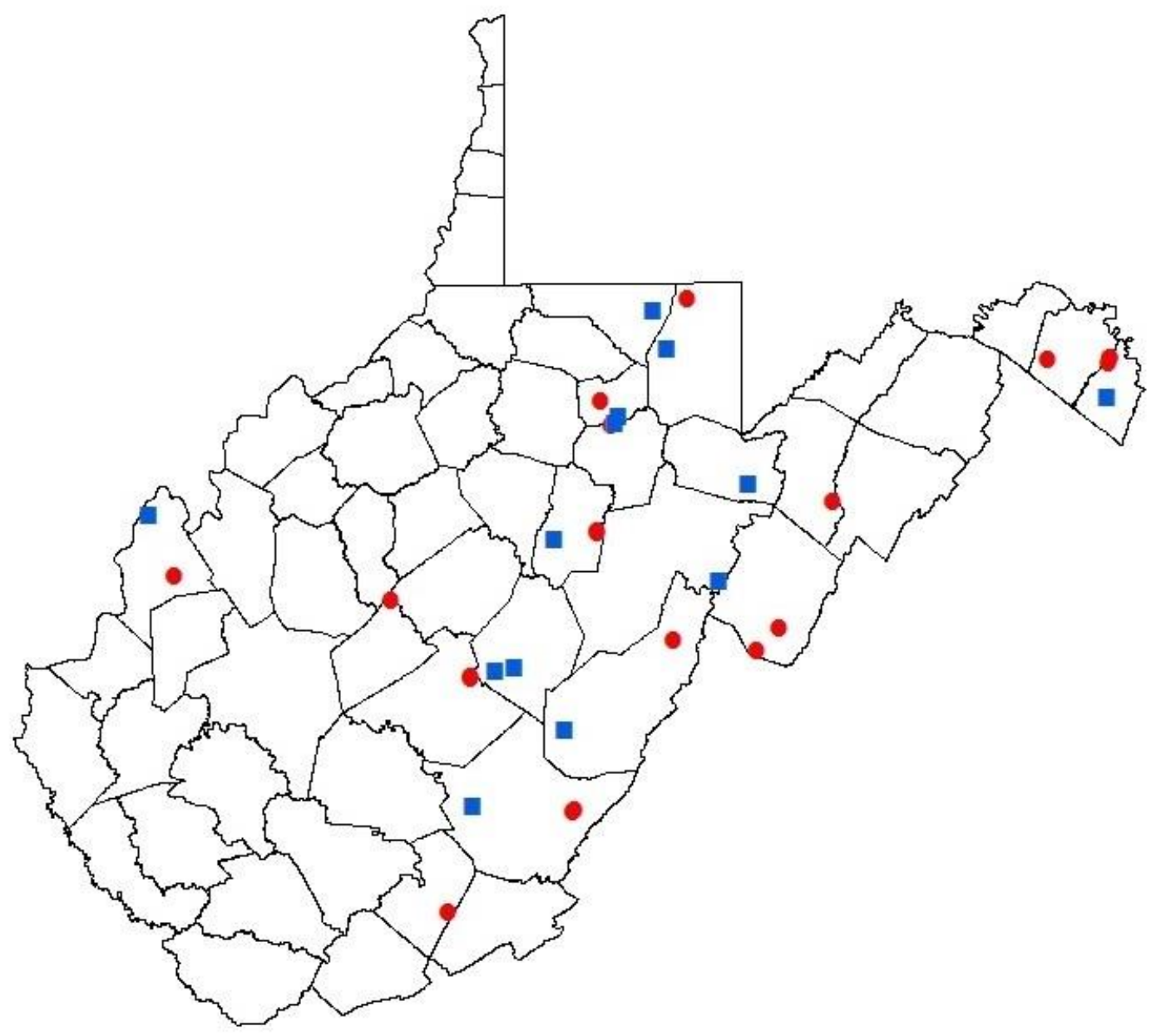

- Reference

- $\quad$ ACEP

Figure 1. All wetlands enrolled in the Agricultural Conservation Easement Program (ACEP) administered through the Natural Resources Conservation Service in West Virginia, USA along with reference wetlands located on public land on wildlife management areas, state parks, and The Nature Conservancy land. Blue squares represent reference sites and red circles represent ACEP wetland sites. 


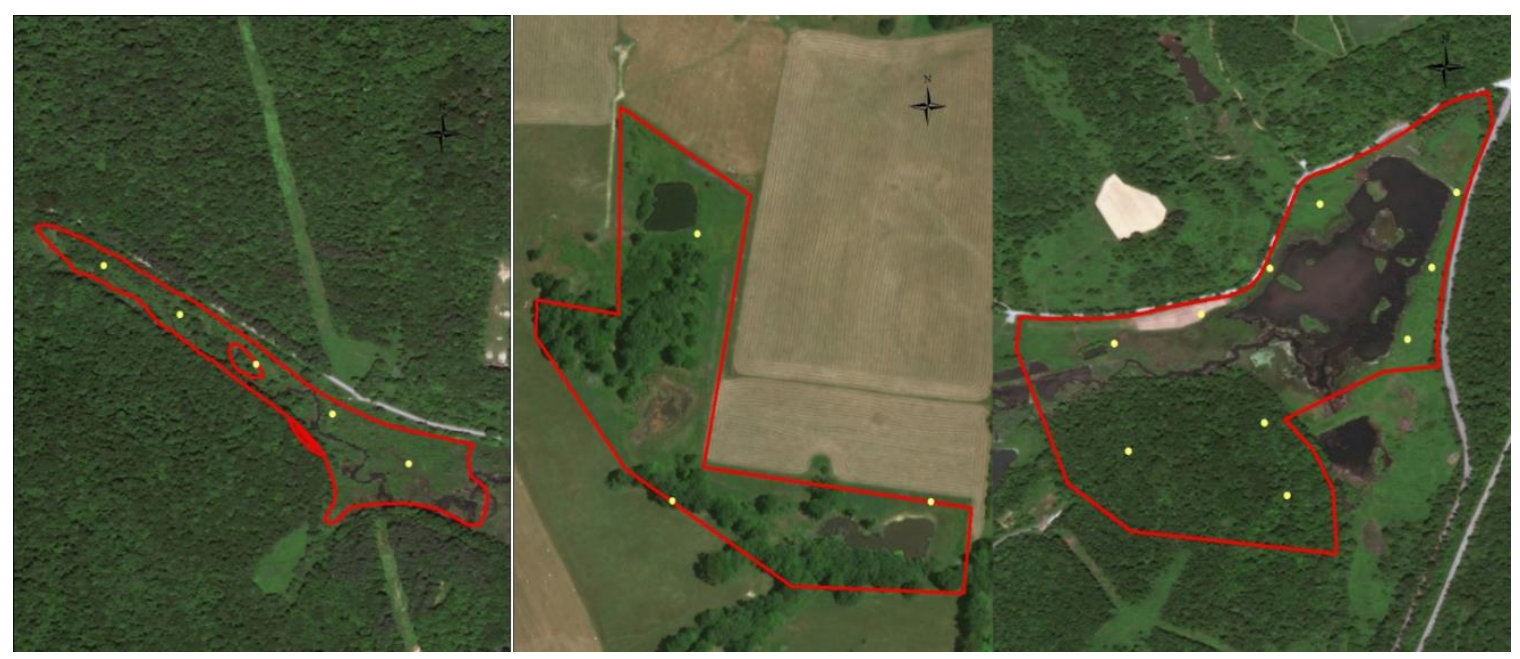

Figure 2. Placement of point count surveys to determine sparrow occupancy and species richness at wetlands in West Virginia, USA. Yellow dots represent point count locations. Red polygons represent wetland boundaries. 


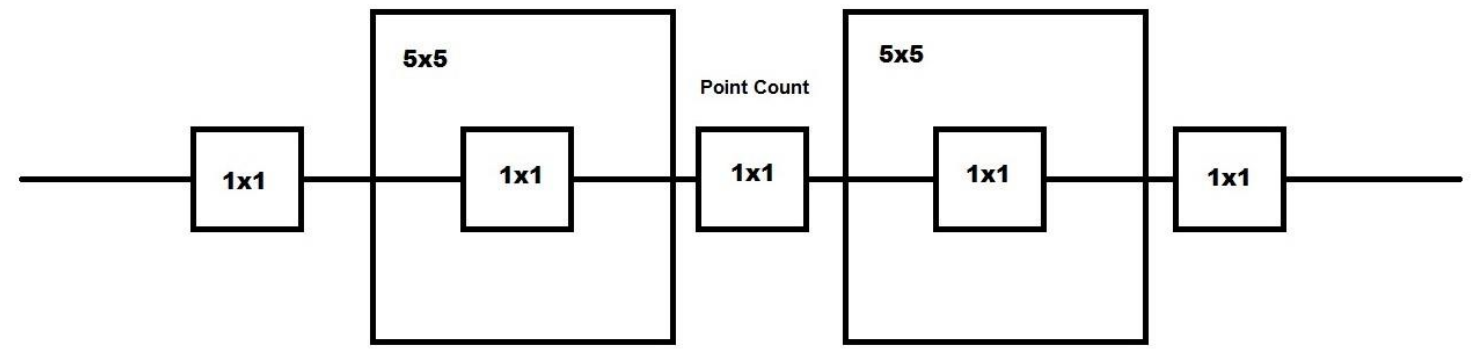

Figure 3. Nested quadrat design used to measure horizontal vegetative cover at each point location on Agricultural Conservation Easement Program (ACEP) and reference wetlands located in West Virginia, USA. Five 1x1 m quadrats were placed five $\mathrm{m}$ apart with the point count location serving as the center $1 \mathrm{x} 1 \mathrm{~m}$ quadrat. Within the $1 \mathrm{x} 1$ $\mathrm{m}$ quadrats, percent cover of herbaceous material, shrub, bare-ground, woody vegetation, and water were measured. Within the $5 \times 5$ m quadrats, percent shrub was measured. 

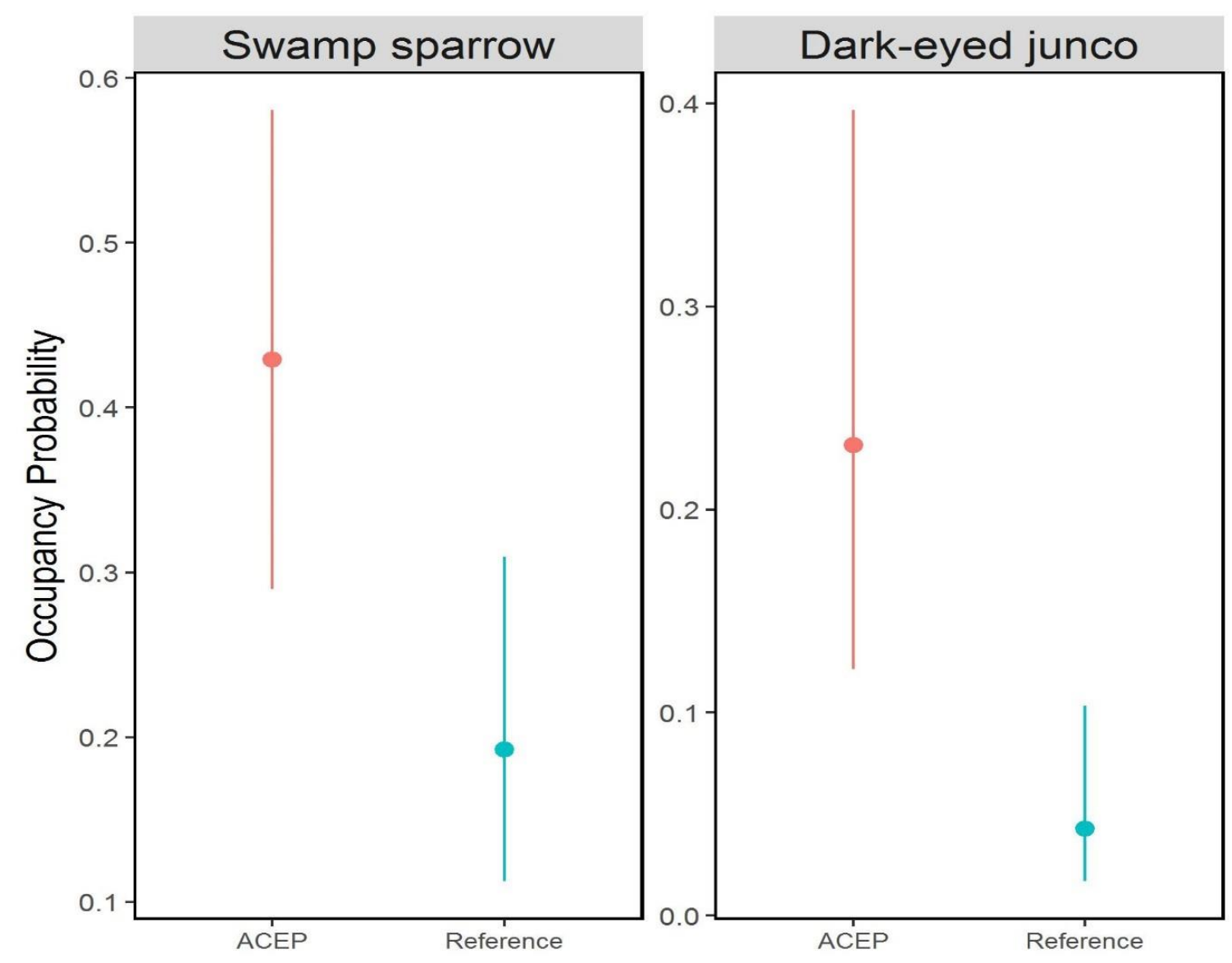

Figure 4. Swamp sparrow and dark-eyed junco occupancy probabilities on Agricultural Conservation Easement Program (ACEP) and reference wetland sites located in West Virginia, USA obtained from detection / non-detection survey data collected in the winters of 2016-2017 and 2017-2018. Occupancy probability differed significantly between ACEP and reference sites for swamp sparrows and dark-eyed juncos. Swamp sparrow occupancy estimates are from the top swamp sparrow occupancy model that included wetland size and year, dark-eyed junco occupancy probability is from the respective top occupancy model that also included the presence of shrub at the $5 \times 5 \mathrm{~m}$ scale and wetland size. 


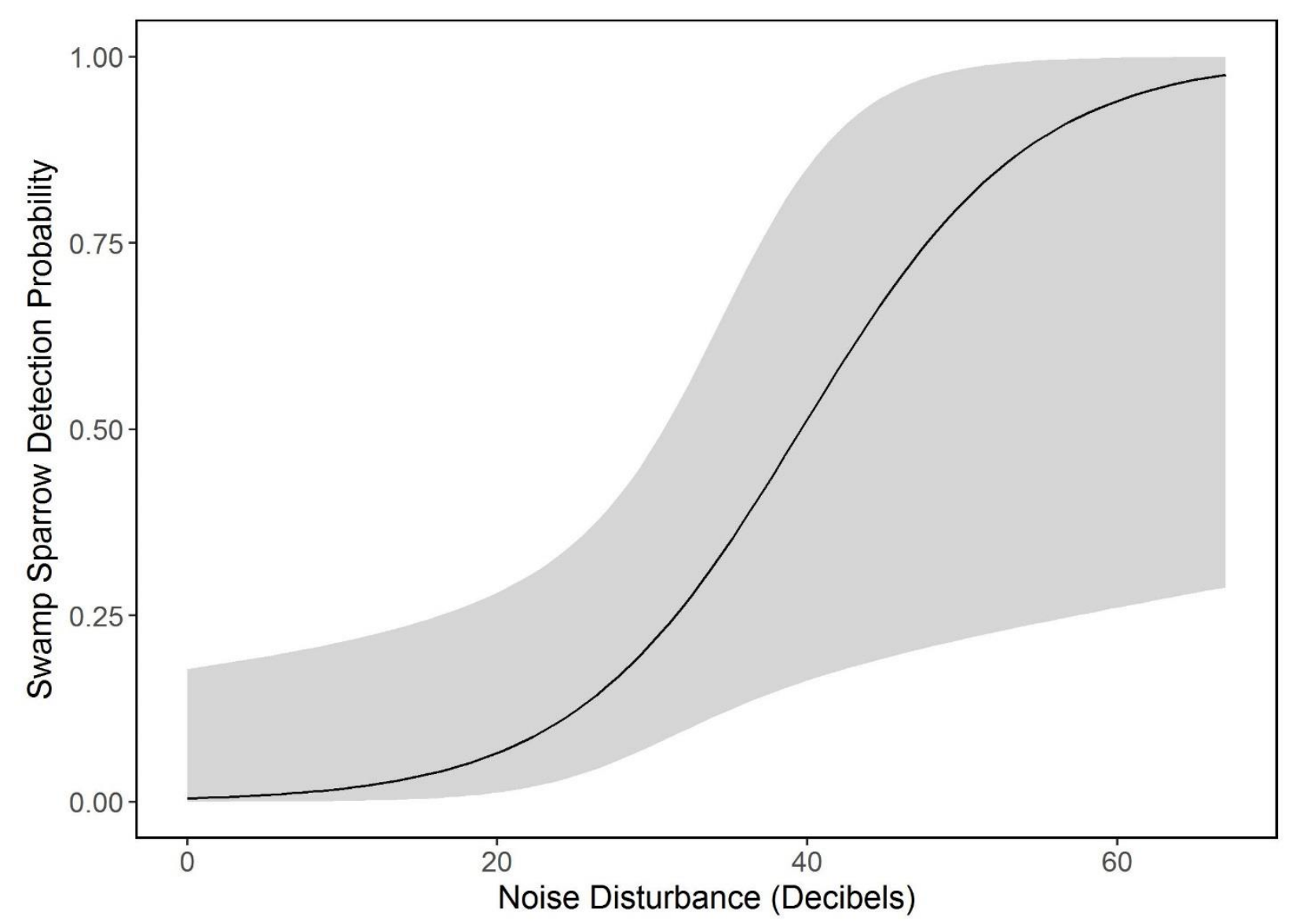

Figure 5. Swamp sparrow detection probability on Agricultural Conservation Easement Program (ACEP) and reference wetland sites located in West Virginia, USA obtained from detection / non-detection survey data collected in the winters of 2016-2017 and 2017-2018. Detection is modeled as a function of the variables included in the top detection model: noise disturbance in decibels 

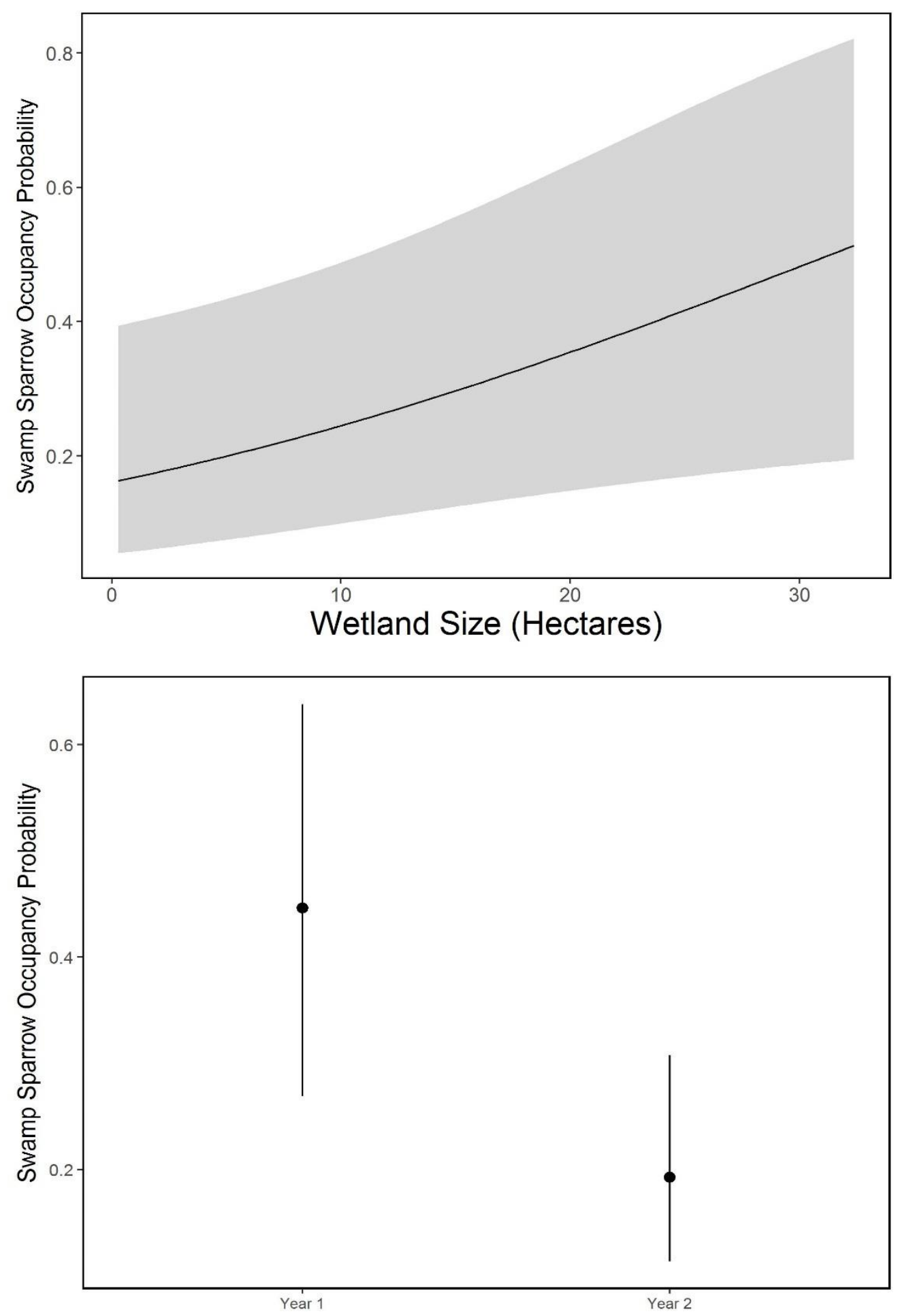

Figure 6. Swamp sparrow occupancy probability on Agricultural Conservation Easement Program (ACEP) and reference wetland sites located in West Virginia, USA obtained from detection / non-detection survey data collected in the winters of 2016-2017 and 2017-2018. Occupancy is modeled as a function of the variables included in the top occupancy model: wetland size in acres (top) and as a function of year (bottom). 

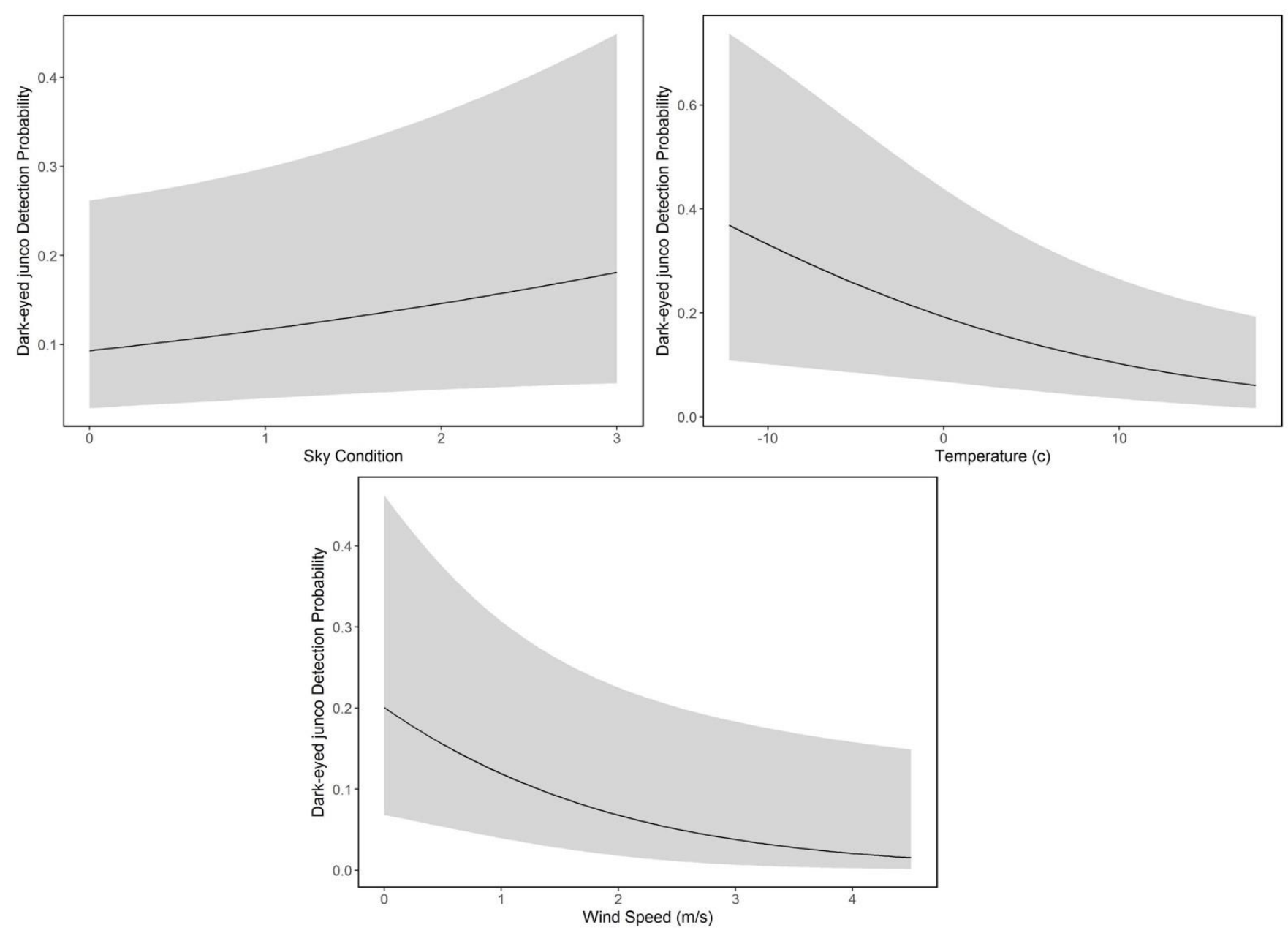

Figure 7. Dark-eyed junco detection probability on Agricultural Conservation Easement Program (ACEP) and reference wetland sites located in West Virginia, USA obtained from detection / non-detection survey data collected in the winters of 2016 - 2017 and 2017-2018. Detection is modeled as a function of the variables included in the top detection model: sky condition on a 1-4 scale, temperature in degrees Celsius and wind speed in meters / second. 

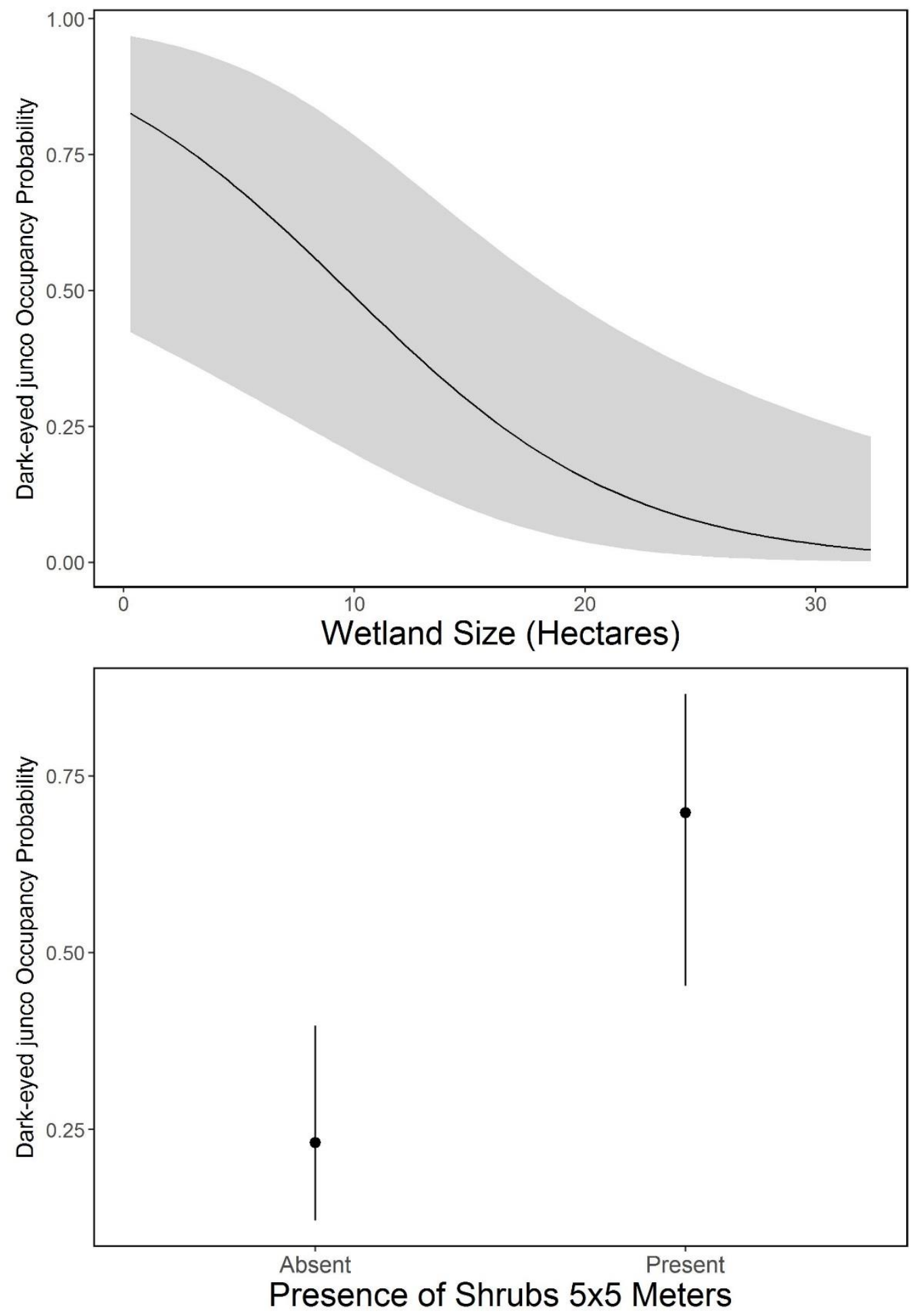

Figure 8. Dark-eyed junco occupancy probability on Agricultural Conservation Easement Program (ACEP) and reference wetland sites located in West Virginia, USA obtained from detection / non-detection survey data collected in the winters of 2016 - 2017 and 2017-2018. Occupancy is modeled as a function of the variables included in the top occupancy model: wetland size (top) and presence of shrubs at the $5 \times 5$ meter scale (bottom). 

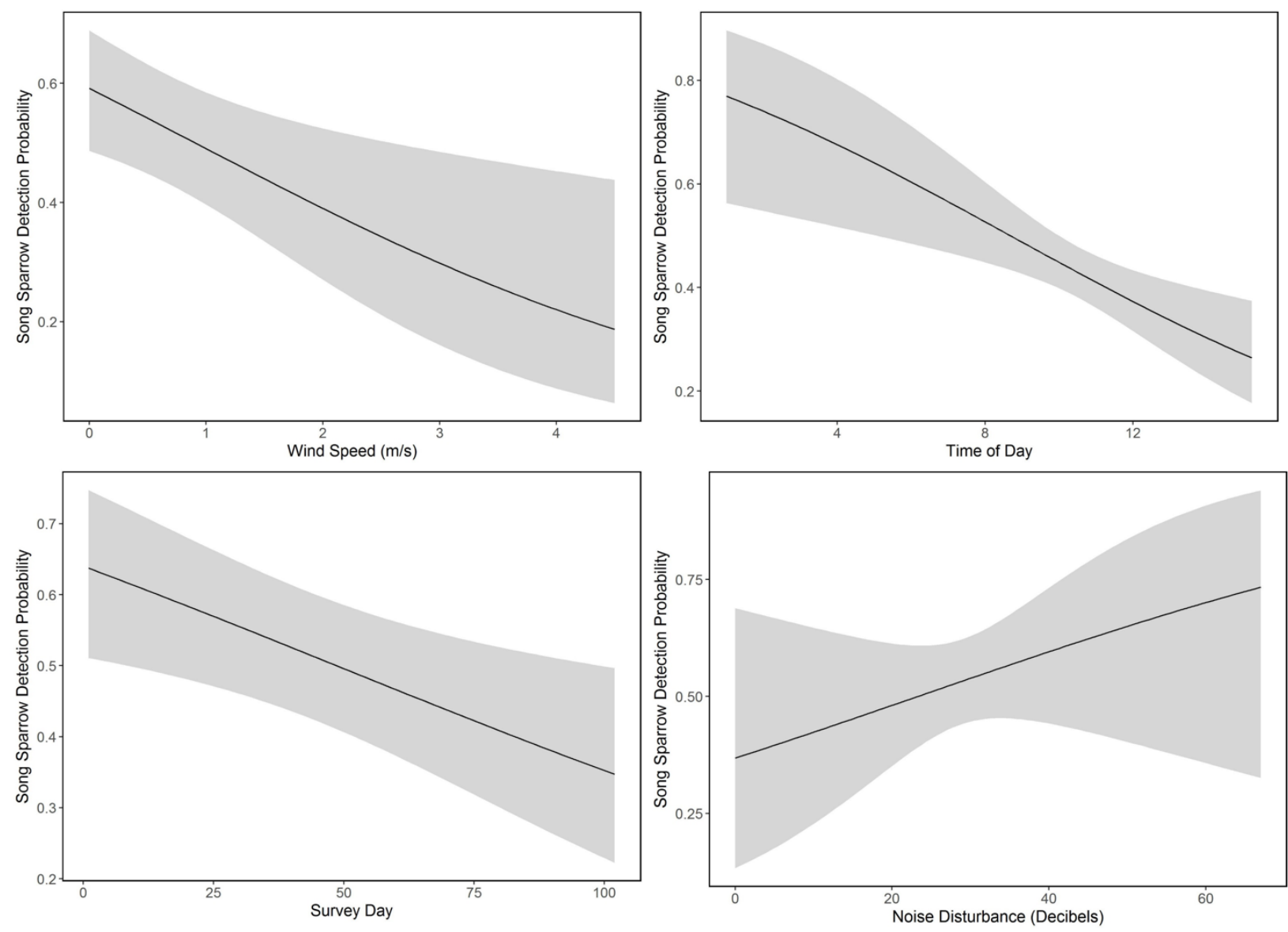

Figure 9. Song sparrow detection probability on Agricultural Conservation Easement Program (ACEP) and reference wetland sites located in West Virginia, USA obtained from detection / non-detection survey data collected in the winters of 2016-2017 and 2017-2018. Detection probability was modeled as a function of the variables included in the top detection model: wind speed in meters / second, time of day in decimal format, survey day of year and noise disturbance in decibels. 


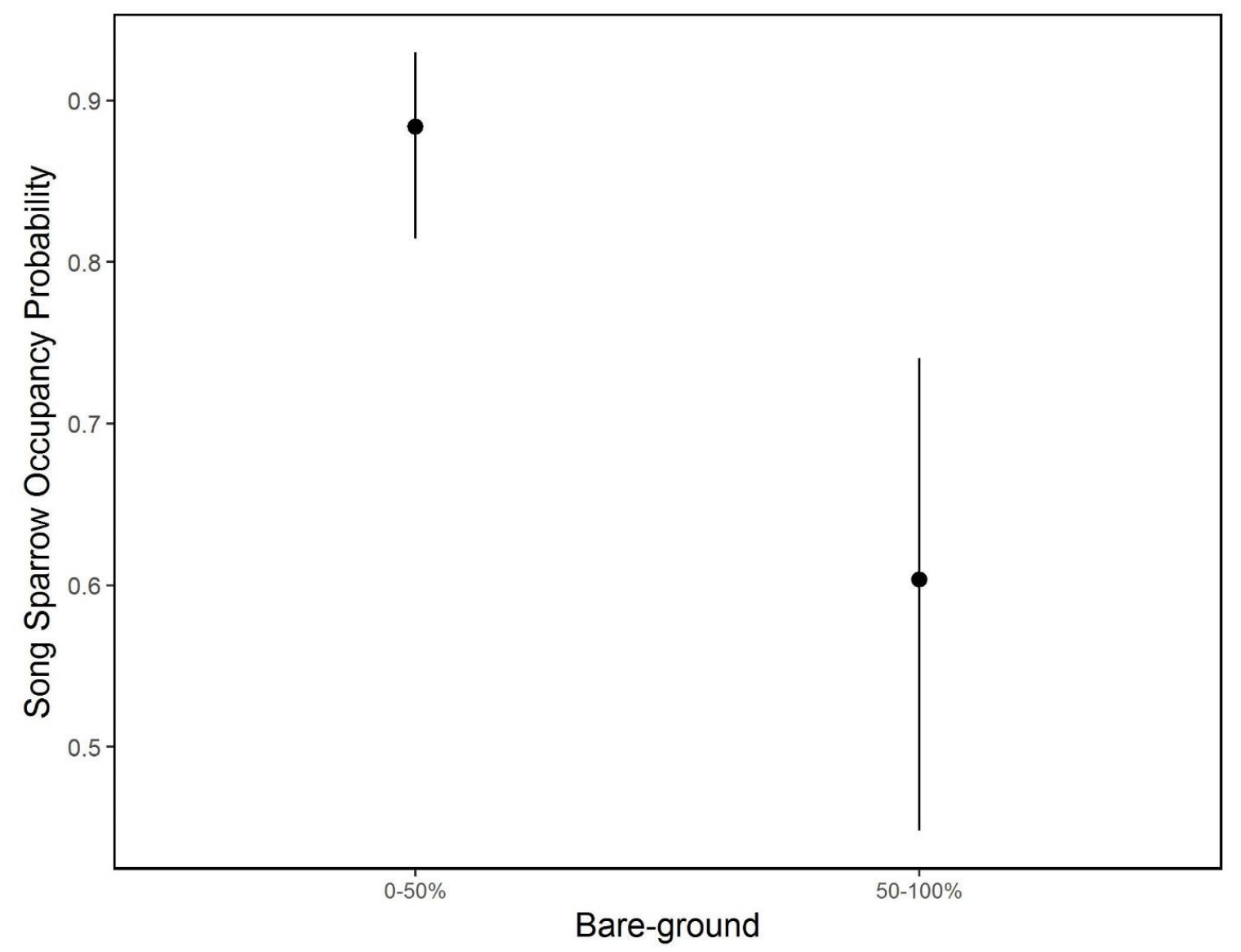

Figure 10. Song sparrow occupancy probability on Agricultural Conservation Easement Program (ACEP) and reference wetland sites located in West Virginia, USA obtained from detection / non-detection survey data collected in the winters of 2016-2017 and 2017-2018. Occupancy is modeled as a function of the variables included in the top occupancy model: percent coverage of bare-ground at point count locations. Bare-ground was measured as two categories: $0-50 \%$ coverage or $>50-100 \%$ coverage. 


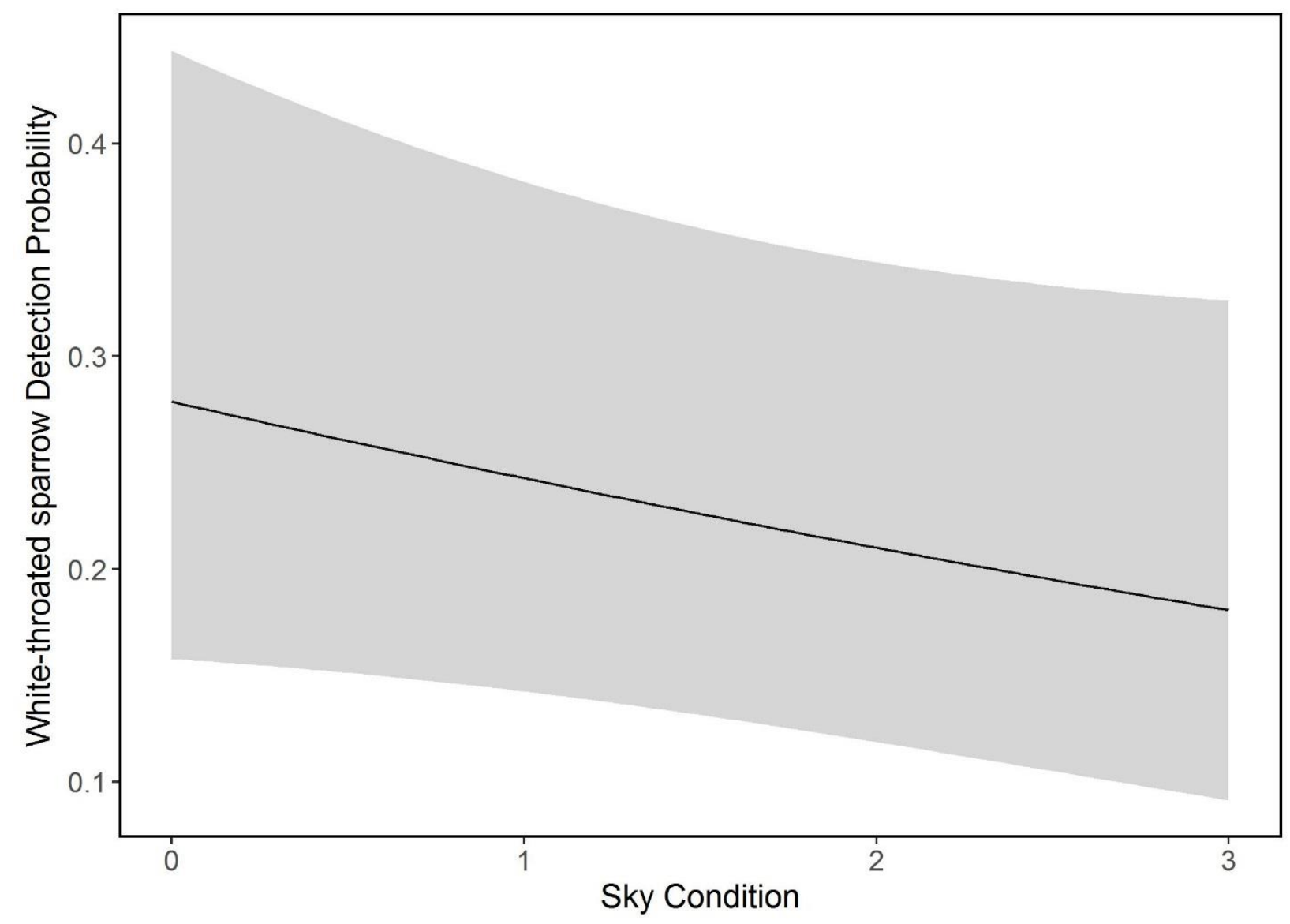

Figure 11. White-throated sparrow detection probability on Agricultural Conservation Easement Program (ACEP) and reference wetland sites located in West Virginia, USA obtained from detection / non-detection survey data collected in the winters of 2016 - 2017 and 2017-2018. Detection is modeled as a function of the variables included in the top detection model: sky condition on a 1-4 scale 


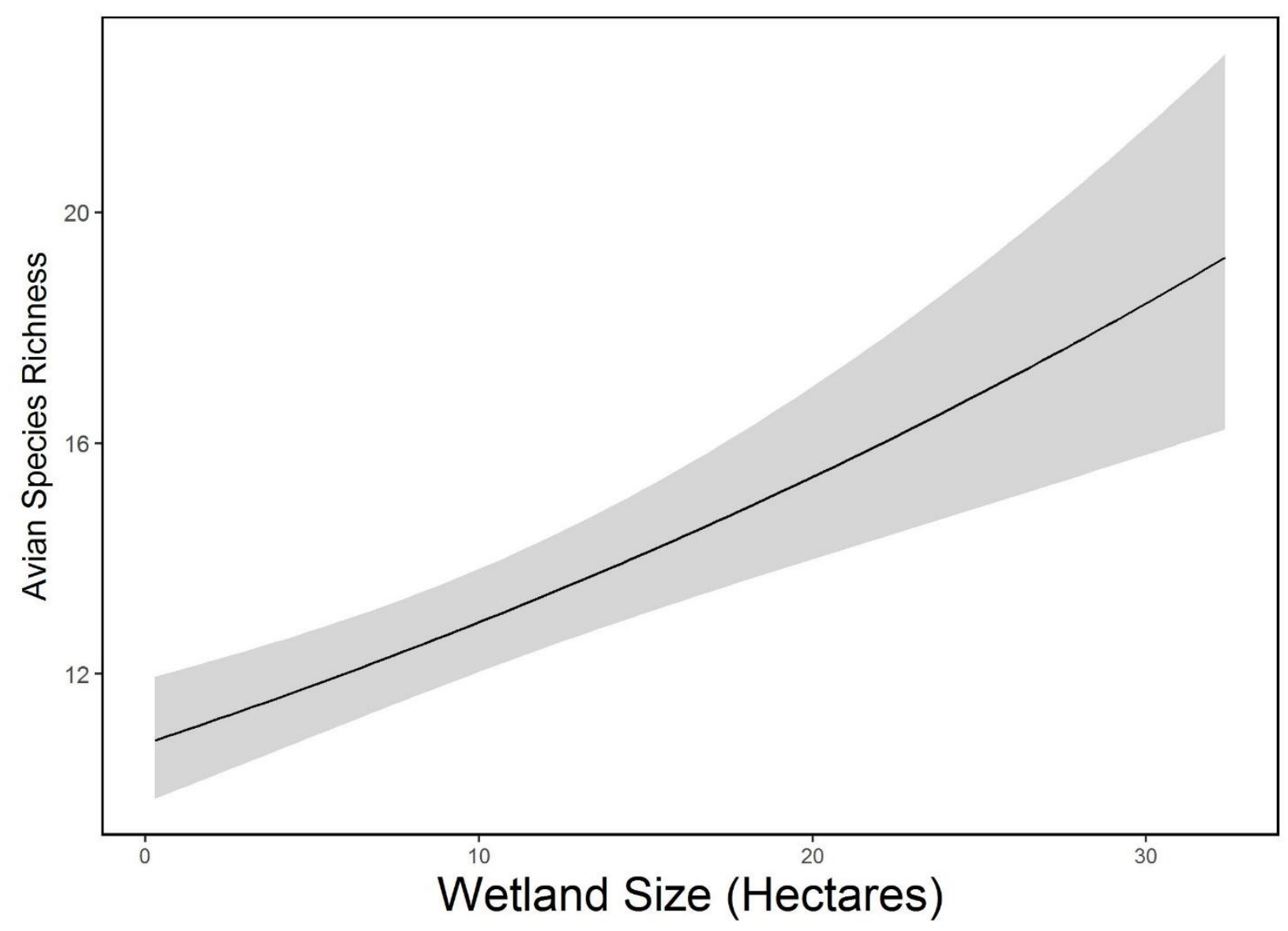

Figure 12. Apparent species richness probability on Agricultural Conservation Easement Program (ACEP) and reference wetland sites located in West Virginia, USA obtained from detection / non-detection survey data collected in the winters of 2016-2017 and 2017-2018. Apparent richness is modeled as a function of the top predictor we modeled: wetland size. Apparent species richness was positively correlated with wetland size. 
Table 1. Detection and occupancy covariates used to model occupancy of Passerellidae sparrows on Agricultural Conservation Easement Program (ACEP) wetlands and reference wetlands located in West Virginia. Levels indicate the categories or units the covariate was measured in.

\begin{tabular}{|c|c|c|}
\hline Covariate Name & Occupancy / Detection & Levels \\
\hline Noise & Detection & Continuous (decibels) \\
\hline Wind speed & Detection & Continuous (meters/second) \\
\hline Sky condition & Detection & $\begin{array}{l}0: \text { clear skies } \\
\text { 1: partly cloudy } \\
\text { 2: overcast } \\
\text { 3: light precipitation } \\
\text { 4: heavy precipitation }\end{array}$ \\
\hline Temperature & Detection & Continuous $\left({ }^{\circ} \mathrm{C}\right)$ \\
\hline Time of day & Detection & Continuous \\
\hline Day of year & Detection & Continuous \\
\hline Herbaceous & Occupancy & $\begin{array}{l}0-25 \% \\
>25-75 \% \\
>75-100 \%\end{array}$ \\
\hline Shrub at the $1 \times 1$ meter scale & Occupancy & $\begin{array}{l}0-25 \% \\
>25-75 \% \\
>75-100 \%\end{array}$ \\
\hline Bare-ground & Occupancy & $\begin{array}{l}0-50 \% \\
>50-100 \%\end{array}$ \\
\hline Water & Occupancy & $\begin{array}{l}\text { Absent } \\
\text { Present }\end{array}$ \\
\hline Woody Vegetation & Occupancy & $\begin{array}{l}\text { Absent } \\
\text { Present }\end{array}$ \\
\hline Shrub at the $5 \times 5$ meter scale & Occupancy & $\begin{array}{l}\text { Absent } \\
\text { Present }\end{array}$ \\
\hline Size & Occupancy & Continuous (ha) \\
\hline Type & Occupancy & $\begin{array}{l}\text { ACEP } \\
\text { Reference }\end{array}$ \\
\hline Year & Occupancy & $\begin{array}{l}\text { Year } 1 \\
\text { Year } 2\end{array}$ \\
\hline
\end{tabular}


Table 2. Passerellidae species detected on Agricultural Conservation Easement Program (ACEP) and reference wetland sites located in West Virginia, USA obtained from detection / non-detection survey data collected in the winters of 2016 - 2017 and 2017-2018 over both survey years and total number of individuals.

\begin{tabular}{lccc}
\hline Species & $\begin{array}{c}\text { Detected on } \\
\text { ACEP }\end{array}$ & $\begin{array}{l}\text { Detected on } \\
\text { Reference }\end{array}$ & Number of Individuals \\
\hline Song sparrow & Yes & Yes & 547 \\
White-throated sparrow & Yes & Yes & 166 \\
Dark-eyed junco & Yes & Yes & 134 \\
Swamp sparrow & Yes & Yes & 68 \\
Eastern towhee & Yes & Yes & 29 \\
Field sparrow & Yes & Yes & 5 \\
White-crowned sparrow & Yes & No & 5 \\
American tree sparrow & Yes & No & 4 \\
Fox sparrow & Yes & No & 2 \\
Savannah sparrow & Yes & No & 1 \\
\hline
\end{tabular}


Table 3. Top detection and occupancy models for song sparrow, swamp sparrow, dark-eyed junco, and white-throated sparrow occupancy, on Agricultural Conservation Easement Program (ACEP) and reference wetland sites located in West Virginia, USA obtained from detection / non-detection survey data collected in the winters of 2016-2017 and 2017-2018 with top occupancy models indicated by bold type.

\begin{tabular}{|c|c|c|c|c|c|}
\hline Species & Detection Model & Occupancy Model & AIC & $\Delta \mathrm{AIC}$ & $\begin{array}{l}\text { Cumulative } \\
\text { Weight }\end{array}$ \\
\hline \multirow[t]{6}{*}{ Song sparrow } & Noise + day + time + wind speed & Constant & 514.38 & 0.00 & 0.83 \\
\hline & $\begin{array}{l}\text { Noise+day+ time+ temperature+ } \\
\text { wind speed + sky condition }\end{array}$ & Constant & 517.49 & 3.12 & 1.00 \\
\hline & Intercept only & Intercept only & 535.72 & 21.35 & 1.00 \\
\hline & Noise+day+ time + wind speed & Bare ground +Year & 496.40 & 0.00 & 0.89 \\
\hline & Noise + day + time + wind speed & $\begin{array}{l}\text { Herbaceous+shrub1m+ } \\
\text { bareground+woody } \\
\text { vegetation }+ \text { shrub } 5 \mathrm{~m}+ \\
\text { size + type + year }\end{array}$ & 500.61 & 4.21 & 1.00 \\
\hline & Intercept only & Intercept only & 535.72 & 39.32 & 1.00 \\
\hline \multirow{6}{*}{$\begin{array}{l}\text { Swamp } \\
\text { sparrow }\end{array}$} & Noise & Constant & 188.21 & 0.00 & 0.86 \\
\hline & $\begin{array}{l}\text { Noise+day+ time+ temperature+ } \\
\text { wind speed }+ \text { sky condition }\end{array}$ & Constant & 192.89 & 4.67 & 0.94 \\
\hline & Intercept only & Intercept only & 193.59 & 5.38 & 1.00 \\
\hline & Noise & $\begin{array}{l}\text { Herbaceous }+ \text { shrub } 1 \mathrm{~m}+ \\
\text { bareground+woody } \\
\text { vegetation }+ \text { shrub } 5 \mathrm{~m}+ \\
\text { size }+ \text { type }+ \text { year }\end{array}$ & 178.16 & 0.00 & 0.80 \\
\hline & Noise & Size + Type + Year & 180.96 & 2.80 & 1.00 \\
\hline & Intercept only & Intercept only & 193.59 & 15.44 & 1.00 \\
\hline \multirow{6}{*}{$\begin{array}{l}\text { Dark-eyed } \\
\text { junco }\end{array}$} & Wind + temperature + sky & Constant & 272.14 & 0.00 & 0.79 \\
\hline & $\begin{array}{l}\text { Noise+day+ time+ temperature+ } \\
\text { wind speed + sky condition }\end{array}$ & Constant & 274.94 & 2.80 & 0.98 \\
\hline & Intercept only & Intercept only & 279.66 & 7.52 & 1.00 \\
\hline & Wind + temperature +sky & $\begin{array}{l}\text { Size + Type + Shrub 5m + } \\
\quad \text { Year }\end{array}$ & 254.10 & 0.00 & 0.95 \\
\hline & Wind + temperature + sky & $\begin{array}{l}\text { Herbaceous }+ \text { shrub } 1 \mathrm{~m}+ \\
\text { bareground+woody } \\
\text { vegetation }+ \text { shrub } 5 \mathrm{~m}+ \\
\text { size }+ \text { type }+ \text { year }\end{array}$ & 260.03 & 5.93 & 1.00 \\
\hline & Intercept only & Intercept only & 279.66 & 25.56 & 1.00 \\
\hline $\begin{array}{l}\text { White- } \\
\text { throated } \\
\text { sparrow }\end{array}$ & Sky & Constant & 409.29 & 0.00 & 0.44 \\
\hline
\end{tabular}




\begin{tabular}{lllll}
\hline Intercept only & Intercept only & $\mathbf{4 0 9 . 4 0}$ & 0.12 & 0.86 \\
\hline $\begin{array}{l}\text { Noise+day+ time+ temperature+ } \\
\text { wind speed + sky condition }\end{array}$ & Constant & 411.52 & 2.23 & 1.00 \\
\hline Intercept only & Intercept only & 409.40 & 0.00 & 0.91 \\
\hline Sky & $\begin{array}{l}\text { Herbaceous+shrub1m+bare } \\
\text { ground+woody } \\
\text { vegetation + shrub 5m + } \\
\text { size + type + year }\end{array}$ & 413.99 & 4.59 & 1.00 \\
& & & \\
\hline
\end{tabular}


Table 4. Number of species detected standardized by number of point counts on Agricultural Conservation Easement Program (ACEP) and reference sites respectively to obtain percent of species ACEP and reference wetland sites located in West Virginia, USA obtained from detection / non-detection survey data collected in the winters of 20162017 and 2017-2018.

\begin{tabular}{|c|c|c|}
\hline Species & $\begin{array}{c}\text { Percent detected on } \\
\text { ACEP }\end{array}$ & Percent detected on Reference \\
\hline American coot (Fulica Americana) & 0.04 & 0 \\
\hline American crow (Corvus brachyrhynchos) & 5.04 & 1.85 \\
\hline American goldfinch(Spinus tristis) & 2.30 & 2.16 \\
\hline American robin (Turdus migratorius) & 1.45 & 0.24 \\
\hline American tree sparrow (Spizella arborea) & 0.05 & 0 \\
\hline Bald eagle (Haliaeetus leucocephalus) & 0.03 & 0.03 \\
\hline Black-capped chickadee(Poecile atricapillus) & 0.10 & 0.01 \\
\hline Belted kingfisher (Megaceryle alcyon) & 0.13 & 0.15 \\
\hline Blue jay (Cyanocitta cristata) & 2.10 & 0.95 \\
\hline Black vulture (Coragyps atratus) & 0 & 0.03 \\
\hline Brown creeper (Certhia americana) & 0.03 & 0.01 \\
\hline Carolina chickadee (Poecile carolinensis) & 0 & 0.01 \\
\hline Canada goose (Branta canadensis) & 0.58 & 1.10 \\
\hline Carolina wren (Thryothorus ludovicianus) & 1.14 & 0.71 \\
\hline cedar waxwing (Bombycilla cedrorum) & 0.27 & 0 \\
\hline Cooper's hawk (Accipiter cooperii) & 0.01 & 0 \\
\hline Common raven (Corvus corax) & 0.70 & 0.28 \\
\hline Dark-eyed junco (Junco hyemalis) & 1.28 & 0.34 \\
\hline Downy woodpecker (Picoides pubescens) & 0.35 & 0.49 \\
\hline Eastern bluebird (Sialia sialis) & 1.34 & 0.47 \\
\hline Eastern phoebe (Sayornis phoebe) & 0.04 & 0.01 \\
\hline Eastern towhee (Pipilo erythrophthalmus) & 0.27 & 0.10 \\
\hline Tufted titmouse (Baeolophus bicolor) & 0.30 & 0.33 \\
\hline European starling (Sturnus vulgaris) & 3.33 & 0.04 \\
\hline Field sparrow (Spizella pusilla) & 0.05 & 0.01 \\
\hline Fox sparrow (Passerella iliaca) & 0.03 & 0 \\
\hline Great blue heron ( Ardea herodias) & 0.03 & 0.05 \\
\hline Golden crowned kinglet (Regulus satrapa) & 0.10 & 0.11 \\
\hline Green-winged teal (Anas carolinensis) & 0.05 & 0 \\
\hline Hairy woodpecker (Leuconotopicus villosus) & 0.03 & 0.038 \\
\hline House finch (Haemorhous mexicanus) & 0.04 & 0.01 \\
\hline House sparrow (Passer domesticus) & 0.03 & 0 \\
\hline Killdeer (Charadrius vociferus) & 0.05 & 0.01 \\
\hline Mallard (Anas platyrhynchos) & 0.13 & 0.15 \\
\hline Mourning dove (Zenaida macroura) & 0 & 0.09 \\
\hline Northern cardinal (Cardinalis cardinalis) & 0.92 & 0.47 \\
\hline Northern flicker (Colaptes auratus) & 0.16 & 0.05 \\
\hline Northern mockingbird (Mimus polyglottos) & 0.30 & 0.05 \\
\hline
\end{tabular}




\begin{tabular}{lrr}
\hline Osprey (Pandion haliaetus) & 0.04 & 0 \\
Pied-billed grebe (Podilymbus podiceps) & 0.01 & 0.01 \\
Pine siskin (Spinus pinus) & 0 & 0.03 \\
Pileated woodpecker (Hylatomus pileatus) & 0.34 & 0.13 \\
Purple finch (Haemorhous purpureus) & 0 & 0.03 \\
Red-bellied woodpecker (Melanerpes carolinus) & 0.14 & 0.15 \\
Ruby-crowned kinglet (Regulus calendula) & 0.01 & 0 \\
Red shouldered hawk (Buteo lineatus) & 0.19 & 0.04 \\
Red tailed hawk (Buteo jamaicensis) & 0.08 & 0.05 \\
Ruffed grouse (Bonasa umbellus) & 0.05 & 0.01 \\
Red-winged blackbird (Agelaius phoeniceus) & 0.08 & 0.10 \\
Savannah sparrow (Passerculus sandwichensis) & 0.01 & 0 \\
Song sparrow (Melospiza melodia) & 5.38 & 1.53 \\
Sharp-shinned hawk (Accipiter striatus) & 0.03 & 0.01 \\
Swamp sparrow (Melospiza georgiana) & 0.73 & 0.13 \\
Turkey vulture (Cathartes aura) & 0.54 & 1.24 \\
Unknown chickadee (Poecile spp.) & 2.29 & 1.78 \\
White-breasted nuthatch (Sitta carolinensis) & 0.81 & 0.67 \\
White-crowned sparrow (Zonotrichia & 0.06 & 0 \\
leucophrys) & & \\
Wilson's snipe (Gallinago delicata) & 0.03 & 0.01 \\
Winter wren (Troglodytes hiemalis) & 0.03 & 0.03 \\
Wood duck (Aix sponsa) & 1.42 & 0.01 \\
White-throated sparrow (Zonotrichia albicollis) & 0.04 & 0.03 \\
Yellow-bellied sapsucker (Sphyrapicus varius) & & 0.01 \\
Yellow-rumped warbler (Setophaga coronata) & & 0.68 \\
& & 0.01 \\
\end{tabular}




\section{Literature Cited}

Ambuel, B. and S.A. Temple. 1983. Area-dependent changes in the bird communities and vegetation of southern Wisconsin forests. Ecology. 64(5): 1057-1068.

Anderson, J.T., and L.M. Smith. 1998. Protein and energy production in Playas: implications for migratory bird management. Wetlands. 18(3): 437-446.

Anderson, J.T. and L.M. Smith. 2000. Invertebrate response to moist-soil management of playa wetlands. Ecological Applications. 10(2): 550-558.

Balcombe, C.K., J.T. Anderson, R.H. Fortney, J.S. Rentch, W.N. Grafton,W.S. Kordek. 2005a. A comparison of plant communities in mitigation and reference wetlands in the MidAppalachians. Wetlands. 25(1): 130-142

Balcombe, C.K., J.T. Anderson, R.H. Fortney, W.S. Kordek. 2005b. Aquatic macroinvertebrate assemblages in mitigated and natural wetlands. Hydrobiologia. 541: 175-188

Balcombe, C.K., J.T. Anderson, R.H. Fortney, W.S. Kordek. 2005c. Wildlife use of mitigation and reference wetlands in West Virginia. Ecological Engineering. 25: 85-99

Baldwin, H.Q., J.B. Grace, W.C. Barrow Jr., R.C. Rohwer. 2007. Habitat relationships of birds overwintering in a managed coastal prairie. The Wilson Journal of Ornithology. 119(2):189-197. Beck, C.W., and B.D. Watts. 1997. The effect of cover and food on space use by wintering song sparrows and field sparrows. Canadian Journal of Zoology. 75:1636-1641.

Blank, P.J., J.R. Parks, G.P. Dively. 2011. Wintering bird response to fall mowing of herbaceous buffers. The Wilson Journal of Ornithology. 123(1): 59-64.

Carr, J.M., and S.L. Lima. 2014. Wintering birds avoid warm sunshine: predation and the costs of foraging in sunlight. Oecologia. 174: 713-721. 
Clipp, H.L., M.L. Peters, J.T. Anderson. 2017. Winter waterbird community composition and use at created wetlands in West Virginia, USA. Scientifica.

Cowardin, L.M., V. Carter, F.C. Golet, E. T. LaRoe. 1979. Classification of wetlands and deepwater habitats of the United States. United States Fish and Wildlife Service, Washington D.C. USA.

Dahl, T.E. 2011. Status and trends of wetlands in the conterminous United States 2004 to 2009. U.S. Department of the Interior, Fish and Wildlife Service, Washington D.C.

Daubenmire, R.F. 1959. Canopy coverage method of vegetation analysis. Northwest Science $33: 43-64$.

Elphick, C., J.B. Dunning Jr., D.A. Sibley. 2001. The Sibley guide to bird life and behavior. Alfred A. Knopf, New York, USA.

ESRI. 2016. ArcGIS Desktop: Release 10.4. Redlands, CA: Environmental Systems Research Institute.

Fiske, I., and R. Chandler 2011. unmarked: An R Package for Fitting Hierarchical Models of Wildlife Occurrence and Abundance. Journal of Statistical Software, 43(10), 1-23. URL http://www.jstatsoft.org/v43/i10/.

Fretwell, J.D., J.S. Williams, P.J. Redman. 1996. National water summary on wetland resources. U.S. Geological Survey. Washington D.C., USA.

Harms, T.M., and S.J. Dinsmore. 2015. Density, abundance, and habitat associations of the inland swamp sparrow (Melospiza Georgiana Georgiana) in Iowa. The Wilson Journal of Ornithology. 127(4): 670-677. 
Kaminski, M.R., G.A. Baldassarre, A.T. Pearse. 2006. Waterbird responses to hydrological management of Wetlands Reserve Program habitats in New York. Wildlife Society Bulletin. 34(4): 921-926.

Kendall, M. G. 1938. A new measure of rank correlation, Biometrika 30: 81-93.

Lee, M., and J.A. Martin. 2017. Avian species and functional diversity in agricultural landscapes: does landscape heterogeneity matter? PLoS ONE 12(1): 1-21.

Lorenzon, R.E., A.H. Beltzer, P.F. Olguin, A.L. Ronchi-Virgolini. 2016. Habitat heterogeneity drives bird species richness, nestedness, and habitat selection by individual species in fluvial wetlands of the Parana River, Argentina. Austral Ecology. 41: 829-841.

MacArthur, R.H., and E.O. Wilson. 1967. The theory of island biogeography. Princeton University Press. Princeton, NJ, USA.

MacKenzie, D. I., J. D. Nichols, G. B. Lachman, S. Droege, J. Andrew Royle, and C. A. Langtimm. 2002. Estimating Site Occupancy Rates When Detection Probabilities Are Less Than One. Ecology 83: 2248-2255.

Marcus, J.F., W.E. Palmer, P.T. Bromley. 2000. The effects of farm field borders on overwintering sparrow densities. The Wilson Bulletin. 112(4):517-523.

Mitsch, W.J., and M.E. Hernandez. 2013. Landscape and climate change threats to wetlands of North and Central America. Aquatic Sciences. 75:133-149.

Moreno-Mateos, D., C. Pedrocchi, F.A. Comin. 2009. Avian communities’ preferences in recently created agricultural wetlands in irrigated landscapes of semi-arid areas. Biodiversity and Conservation. 18: 811-828. 
Morin, R.S., G.M. Domke, B.F. Walters. 2017. Forests of West Virginia, 2016. Resource Update FS-123. United States Department of Agriculture, Forest Service. Newtown Square, PA, USA. Mueller-Dombois, D. and H. Ellenburg. 1974. Aims and methods of vegetation ecology. John Wiley Sons, New York, NY. pp 48-50.

Murkin. H.R., E.J. Murkin, J.P. Ball. 1997. Avian habitat selection and prairie wetland dynamics: a 10 year experiment. Ecological Applications. 7(4): 1144-1159.

Pasinelli, G., C. Mayer, A. Gouskov, K. Schiegg. 2008. Small and large wetland fragments are equally suited breeding sites for a ground-nesting passerine. Oecologia. 156: 703-714.

Plush, C.J., C.E. Moorman, D.B. Orr, C. Reberg-Horton. 2013. Overwintering sparrow use of field borders planted as beneficial insect habitat. The Journal of Wildlife Management. 77(1): 200-206.

Pulliam, H.R. and G.S. Mills. 1977. The use of space by wintering sparrows. Ecology. 58: 13931399.

R Core Team 2016. R: A language and environment for statistical computing. R Foundation for Statistical Computing, Vienna, Austria. URL https://www.R-project.org/.

Ralph, C.J., G.R. Geupel, P. Pyle, T.E. Martin, D.F. DeSante. 1993. Handbook of field methods for monitoring landbirds. U.S. Forest Service, National Agroforestry Center. Pacific Southwest Research Station. Albany, California, USA.

Riffell, S.K., B.E. Keas, T.M. Burton. 2001. Area and habitat relationships of birds in great lakes coastal wet meadows. Wetlands. 21(4): 492-507.

Runkle, J., K. Kunkle, R. Frankson, B. Stewart. 2017. West Virginia state summary. NOAA Technical Report NESDIS 149-WV, 4pp. 
Schneider, K.J. 1984. Dominance, predation, and optimal foraging in white-throated sparrow flocks. Ecology. 65(6): 1820-1827.

Siriwardena, G.M., I.R. Cooke, W.J. Sutherland. 2012. Landscape, cropping and field boundary influences on bird abundance. Ectography. 35: 162-173.

Smith, L.A., and P. Chow-Fraser. 2010. Implications of the species-area relationship on sampling effort for marsh birds in southern Ontario. Wetlands. 30(3): 553-563.

Strain, G.F., P.J. Turk, J.T. Anderson. 2014. Functional equivalency of created and natural wetlands: diet composition of red-spotted newts (Notophthalmus viridescens viridescens). Wetlands Ecology and Management. 22: 659-669.

Tiner, R.W., I. Kenenski, T. Nuerminger, J. Eaton, D.B. Foulis, G.S. Smith, W.E. Frayer. 1994. Recent wetland status and trends in the Chesapeake watershed (1982-1989). U.S. Fish and Wildlife Service Ecological Services Technical Report. Annapolis, Maryland, USA.

U. S. Fish and Wildlife Service. May 2016. National Wetlands Inventory website. U.S. Department of the Interior, Fish and Wildlife Service, Washington, D.C. http://www.fws.gov/wetlands/

West Virginia Geological and Economic Survey. 2017. Physiographic provinces of West Virginia. <http://www.wvgs.wvnet.edu/www/geology/geolphyp.htm>. Accessed 6 April 2018. 
Appendix A. Agricultural Conservation Easement Program (ACEP) wetlands and reference wetlands located in West Virginia, USA. Table includes description of wetland size, county, physiographic region, wetland class, and number of point counts of each site. For ACEP sites, year of restoration is also included.

\begin{tabular}{|c|c|c|c|c|c|c|}
\hline Site & $\begin{array}{l}\text { Wetland } \\
\text { Size (ha) }\end{array}$ & County & $\begin{array}{l}\text { Physiographic } \\
\text { Region }\end{array}$ & Wetland Class & $\begin{array}{l}\text { Number } \\
\text { of Point } \\
\text { Counts }\end{array}$ & $\begin{array}{l}\text { Year } \\
\text { restored } \\
\text { (ACEP) }\end{array}$ \\
\hline ACEP 1 & 4.24110928 & Summers & $\begin{array}{l}\text { Appalachian } \\
\text { Plateau }\end{array}$ & forested/scrub-shrub & 2 & 2010 \\
\hline ACEP 2 & 1.318466988 & Greenbriar & $\begin{array}{l}\text { Appalachian } \\
\text { Plateau }\end{array}$ & palustrine emergent & 2 & 2010 \\
\hline ACEP 3 & 3.2172537 & Greenbriar & $\begin{array}{l}\text { Appalachian } \\
\text { Plateau }\end{array}$ & $\begin{array}{l}\text { forested / palustrine } \\
\text { emergent }\end{array}$ & 5 & 2012 \\
\hline ACEP 4 & 1.82918072 & Upshur & $\begin{array}{l}\text { Appalachian } \\
\text { Plateau }\end{array}$ & palustrine emergent & 4 & 1998 \\
\hline ACEP 5 & 3.87689188 & Jefferson & Great Valley & $\begin{array}{l}\text { forested/ palustrine } \\
\text { emergent }\end{array}$ & 3 & 1998 \\
\hline ACEP 6 & 18.58318112 & Nicholas & $\begin{array}{l}\text { Appalachian } \\
\text { Plateau }\end{array}$ & scrub-shrub & 1 & 1998 \\
\hline ACEP 7 & 6.58019436 & Jefferson & Great Valley & $\begin{array}{l}\text { forested/ palustrine } \\
\text { emergent }\end{array}$ & 4 & 1999 \\
\hline ACEP 8 & 6.1107586 & Pendleton & Valley and Ridge & $\begin{array}{l}\text { forested/ palustrine } \\
\text { emergent }\end{array}$ & 3 & 2011 \\
\hline ACEP 9 & 28.6922374 & Mason & $\begin{array}{l}\text { Appalachian } \\
\text { Plateau }\end{array}$ & palustrine emergent & 8 & 1996 \\
\hline ACEP 10 & 27.95166202 & Nicholas & $\begin{array}{l}\text { Appalachian } \\
\text { Plateau }\end{array}$ & forested & 5 & 1999 \\
\hline ACEP 11 & 0.404686 & Pendleton & Valley and Ridge & palustrine emergent & 1 & 2010 \\
\hline ACEP 12 & 1.72800922 & Jefferson & Great Valley & palustrine emergent & 1 & 1998 \\
\hline ACEP 13 & 1.40830728 & Clay & $\begin{array}{l}\text { Appalachian } \\
\text { Plateau }\end{array}$ & palustrine emergent & 2 & 2001 \\
\hline ACEP 14 & 6.0298214 & Pocahontas & $\begin{array}{l}\text { Appalachian } \\
\text { Plateau }\end{array}$ & scrub-shrub & 5 & 1998 \\
\hline ACEP 15 & 0.9105435 & Grant & $\begin{array}{l}\text { Alleghany } \\
\text { Mountain }\end{array}$ & palustrine emergent & 3 & 2011 \\
\hline ACEP 16 & 16.76209412 & Berkeley & Great Valley & palustrine emergent & 7 & 1996 \\
\hline ACEP 17 & 3.6826426 & Upshur & $\begin{array}{l}\text { Appalachian } \\
\text { Plateau }\end{array}$ & palustrine emergent & 2 & 1999 \\
\hline ACEP 18 & 4.249203 & Preston & $\begin{array}{l}\text { Alleghany } \\
\text { Mountain }\end{array}$ & palustrine emergent & 3 & 1998 \\
\hline ACEP 19 & 32.37488 & Barbour & $\begin{array}{l}\text { Appalachian } \\
\text { Plateau }\end{array}$ & palustrine emergent & 9 & 1997 \\
\hline ACEP 20 & 3.83237642 & Taylor & $\begin{array}{l}\text { Appalachian } \\
\text { Plateau }\end{array}$ & palustrine emergent & 5 & 1998 \\
\hline Reference 1 & 4.54057692 & Webster & $\begin{array}{l}\text { Appalachian } \\
\text { Plateau }\end{array}$ & forested/scrub shrub & 3 & \\
\hline Reference 2 & 7.23173882 & Monongalia & $\begin{array}{l}\text { Appalachian } \\
\text { Plateau }\end{array}$ & palustrine emergent & 4 & \\
\hline Reference 3 & 25.17956292 & Jefferson & Great Valley & palustrineemergent & 7 & \\
\hline Reference 4 & 0.27923334 & Webster & $\begin{array}{l}\text { Appalachian } \\
\text { Plateau }\end{array}$ & palustrine emergent & 1 & \\
\hline Reference 5 & 9.712464 & Mason & $\begin{array}{l}\text { Appalachian } \\
\text { Plateau }\end{array}$ & palustrine emergent & 4 & \\
\hline
\end{tabular}




\begin{tabular}{llllll}
\hline Reference 6 & 25.68946728 & Greenbriar & $\begin{array}{l}\text { Appalachian } \\
\text { Plateau }\end{array}$ & forested /scrub-shrub & 5 \\
Reference 7 & 3.44387786 & Randolph & $\begin{array}{l}\text { Alleghany } \\
\text { Mountain }\end{array}$ & palustrineemergent & 3 \\
Reference 8 & 6.6975533 & Pocahontas & $\begin{array}{l}\text { Appalachian } \\
\text { Plateau }\end{array}$ & palustrine emergent & 5 \\
Reference 9 & 14.2651815 & Tucker & $\begin{array}{l}\text { Alleghany } \\
\text { Mountain }\end{array}$ & $\begin{array}{l}\text { palustrine } \\
\text { emergent/forested/scrub- } \\
\text { shrub } \\
\text { palustrine emergent }\end{array}$ & 6 \\
Reference 10 & 0.9510121 & Upshur & $\begin{array}{l}\text { Appalachian } \\
\text { Plateau }\end{array}$ & $\begin{array}{l}\text { Alleghany } \\
\text { Mountain } \\
\text { palustrine emergent }\end{array}$ & 3 \\
Reference 11 & 7.5271596 & Preston & Batachian & forested/scrub-shrub & 2 \\
Reference 12 & 2.90564548 & Barbour & $\begin{array}{l}\text { Appalachian } \\
\text { Plateau }\end{array}$ & forested/scrub -shrub & 4 \\
\hline
\end{tabular}


Appendix B. Counts of observed Macroinvertebrate families and Shannon-Weaver diversity index on each Agricultural Conservation Easement Program (ACEP) wetland and reference wetland located in West Virginia, USA collected in May of 2017

\begin{tabular}{|c|c|c|c|c|c|c|c|}
\hline Site & Prosobranchia & Chironomidae & Enchytraeidae & Tabanidae & Lumbriculidae & Dytiscidae & Diversity Index \\
\hline ACEP 1 & 0 & 0 & 1 & 0 & 0 & 0 & 0 \\
\hline ACEP 2 & 0 & 0 & 0 & 0 & 0 & 0 & 0 \\
\hline ACEP 3 & 0 & 0 & 0 & 0 & 0 & 0 & 0 \\
\hline ACEP 4 & 0 & 0 & 0 & 0 & 0 & 0 & 0 \\
\hline ACEP 5 & 0 & 0 & 0 & 0 & 0 & 0 & 0 \\
\hline ACEP 6 & 0 & 0 & 0 & 0 & 0 & 0 & 0 \\
\hline ACEP 7 & 14 & 1 & 0 & 0 & 0 & 0 & 0.244930027 \\
\hline ACEP 8 & 0 & 0 & 0 & 0 & 0 & 0 & 0 \\
\hline ACEP 9 & 0 & 0 & 1 & 0 & 0 & 0 & 0 \\
\hline ACEP 10 & 0 & 0 & 0 & 0 & 0 & 0 & 0 \\
\hline ACEP 11 & 0 & 0 & 0 & 0 & 0 & 0 & 0 \\
\hline ACEP 12 & 0 & 0 & 0 & 0 & 0 & 0 & 0 \\
\hline ACEP 13 & na & na & na & na & na & na & na \\
\hline ACEP 14 & 0 & 1 & 0 & 0 & 0 & 0 & 0 \\
\hline ACEP 15 & 0 & 0 & 0 & 1 & 0 & 0 & 0 \\
\hline ACEP 16 & 0 & 0 & 26 & 0 & 0 & 0 & 0 \\
\hline ACEP 17 & 0 & 0 & 0 & 0 & 0 & 0 & 0 \\
\hline ACEP 18 & 0 & 0 & 0 & 0 & 0 & 0 & 0 \\
\hline ACEP 19 & 4 & 0 & 0 & 0 & 0 & 0 & 0 \\
\hline ACEP 20 & 0 & 0 & 0 & 1 & 0 & 0 & 0 \\
\hline Reference 1 & 0 & 0 & 0 & 0 & 0 & 0 & 0 \\
\hline Reference 2 & 0 & 0 & 0 & 1 & 0 & 0 & 0 \\
\hline Reference 3 & na & na & na & na & na & na & na \\
\hline Reference 4 & 0 & 0 & 0 & 0 & 0 & 0 & 0 \\
\hline Reference 5 & 0 & 0 & 0 & 1 & 0 & 0 & 0 \\
\hline Reference 6 & na & na & na & na & na & na & na \\
\hline Reference 7 & 0 & 0 & 0 & 0 & 0 & 0 & 0 \\
\hline Reference 8 & na & na & na & na & na & na & na \\
\hline Reference 9 & 0 & 0 & 0 & 0 & 0 & 0 & 0 \\
\hline Reference 10 & 0 & 0 & 0 & 3 & 0 & 0 & 0 \\
\hline Reference 11 & 0 & 0 & 0 & 9 & 0 & 1 & 0.32 \\
\hline Reference 12 & 0 & 0 & 0 & 0 & 1 & 0 & 0 \\
\hline Reference 13 & 0 & 0 & 0 & 0 & 0 & 0 & 0 \\
\hline
\end{tabular}

